\title{
CuCrO4 Nanoparticles Composite Modified Carbon Paste Electrodes for Sensitive Detection of Paracetamol: A Cyclic Voltammetric Study
}

\section{PRIYANKA S R}

Department of P.G. Studies and Research in Chemistry, Sahyadri Science College, Shivamogga-577 201, Karnataka (S), INDIA https://orcid.org/0000-0003-1489-4327

Latha K.P (D latha119@gmail.com )

Department of P.G. Studies and Research in Chemistry, Sahyadri Science College, Shivamogga-577 201, Karnataka (S), INDIA

\section{Research Article}

Keywords: CuCrO4 Nanocomposites, MCPE, Paracetamol, Hydrothermal method, Copper chromate

Posted Date: April 16th, 2021

DOI: https://doi.org/10.21203/rs.3.rs-411115/v1

License: (a) (i) This work is licensed under a Creative Commons Attribution 4.0 International License. Read Full License 


\title{
$\mathrm{CuCrO}_{4}$ Nanoparticles Composite Modified Carbon Paste Electrodes for Sensitive
} Detection of Paracetamol: A Cyclic Voltammetric Study

$\underline{\text { S R Priyanka and K.P. Latha* }}$

Department of P.G. Studies and Research in Chemistry, Sahyadri Science College, Shivamogga-577 201, Karnataka (S), INDIA

*E mail: latha119@gmail.com, priyankasr12345@gmail.com

\begin{abstract}
An electrochemical sensor containing carbon paste electrode (CPE) for paracetamol is developed and modified with the $\mathrm{CuCrO}_{4}$ Nanocomposites. The synthesised $\mathrm{CuCrO}_{4}$ Nanocomposites was discussed with X-Ray Diffraction studies. Experimental studies such as scan rate, concentration and $\mathrm{pH}$ was studied by using cyclic voltammetric method. The $\mathrm{CuCrO}_{4}$ Nanocomposites modified $\mathrm{CPE}\left(\mathrm{CuCrO}_{4}\right.$ Nanocomposites $\left.\mathrm{MCPE}\right)$ exhibited excellent electrocatalytic response towards the oxidation of paracetamol (PC). Over potential for oxidation of PC was minimised which considerably enhance the current response on the $\mathrm{CuCrO}_{4}$ Nanocomposites MCPE when compared with bare carbon paste electrode (BCPE). Scan rate study for PC discuss the process of the electrode. Linear calibration curve was obtained with the range of $2 \mu \mathrm{M}$ to $14 \mu \mathrm{M}$ having the detection limit and quantification limit value of $\mathrm{PC}$ is discussed with $\mathrm{CuCrO}_{4}$ Nanocomposites MCPE. This study shows that electrochemical oxidation of $\mathrm{PC}$ at $\mathrm{CuCrO}_{4}$ Nanocomposites MCPE is $\mathrm{pH}$ dependent process.
\end{abstract}

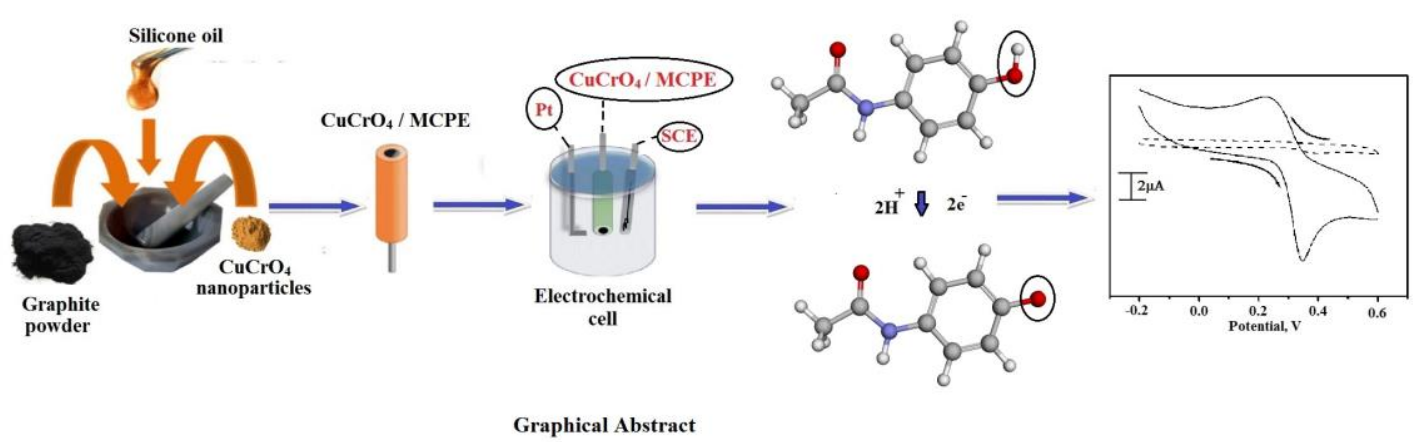


Keywords: $\mathrm{CuCrO}_{4}$ Nanocomposites, MCPE, Paracetamol, Hydrothermal method, Copper chromate

\section{Declaration}

Funding: We hereby declare that the author S. R. Priyanka has the financial assistance from national fellowship for scheduled tribes as fellowship for her Ph. D studies.

Conflict of interest: The authors do not have any conflict of interest.

Availability of data and material: Availability of data and material has transparent.

Code availability: The authors don't have any software Code.

\section{Introduction}

Nanocomposites have wide applications in various fields [1] such as semiconductors [2], catalyst, pigment, drug [3] in the area of electronic and magnetic materials [4-7], and development of electrochemical sensors [8]. From the past two decades the influence of nanocomposites is immense on sensing applications and devices. Sensor is a transducer, which detects/sense some specific vicinities of substances. Numerous active materials have wide range of applications in the field of sensors. The material which includes metals, metal oxides, metal sulphides, metal chromates, composite nanoparticles and many more in their nano $\left(10^{-9}\right)$ dimension. Different methods were discussed for the preparation of metal chromates those were wet chemical, micro emulsion, and sol-gel processes [9]. Ceramic and co-precipitation methods [10]. Electrochemical methods [11] have discussed a variety of applications and synthetic approaches of copper chromite nanocomposites [12]. In the present research work, the most significant stable Copper Chromate nanocomposites $\left(\mathrm{CuCrO}_{4}\right.$ nanocomposites) is prepared through hydrothermal method, which is characterized through XRD. These $\mathrm{CuCrO}_{4}$ nanocomposites being used for the modification of CPE, which is

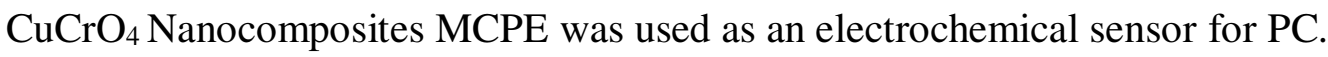


Paracetamol (acetaminophen) (PC) is widely used as a pain reliever and a fever reducer. Many analytical techniques have been used for PC analysis including titrimetry [1314], HPLC [15-17], fluorometry [18], Uv- visible spectrophotometric methods [19], colorimetry [20] and various modes of electrochemistry [21-24]. Since the results of above approaches are not accurate and the techniques involved are tedious and expensive, researchers have shown interest to detect the PC through nanocomposites modified carbon paste electrode. These modified electrodes are inexpensive and showed high sensitivity, minimum detection limit, high accuracy and response. These approaches are simple method to detect the PC through electrochemically. The electrochemical oxidation of PC at nanoparticles modified carbon paste electrode was reported in the earlier work [25]. Recently, the voltammetric behaviour of PC and some other drugs at various conducting polymers were studied [26]. Among all analytical methods, electrochemical methods are best. Electrochemical approaches are effective to quantify the biomarker levels in the blood as they are economic, provide rapid diagnosis and cause less pain in patients. Various electrochemical sensors like norepinephrine (NE), epinephrine (Ep) and Tryptophan (Trp) which are electroactive substances have been reported. Hence electrochemical technique like cyclic voltammetry (CV) technique used under physiological conditions can sensitively detect PC.

$\mathrm{CuCrO}_{4}$ composites show enhanced ionic-conductivity especially for $\mathrm{O}_{2}$ ions; thus, it is generally employed as fuel cells at high temperatures and oxygen sensors [27-28]. This composite also behaves as insulator at moderate temperatures, but it will turn into super ionic conductor at very high temperature. As of its good high hardness, biocompatibility and strength, hence it is frequently used as orthopaedic implants, such as dental implants and femoral head component in hip implants. As deliberated above, it is thermally and chemically firm, joint with its inimitable amphoteric characteristic, making it an idyllic candidate for 
catalyst. For instance, the decomposition of $\mathrm{N}_{2} \mathrm{O}_{2}$, hydrogenation of aromatic carboxylic acids, the isomerization of alkanes, and countless other reactions. $\mathrm{CuCrO}_{4}$ Nanocomposites is a familiar catalyst, holds both the common advantages of transition metal compound catalysts and its own unique merits.

\section{Experimental}

\subsection{Apparatus and Reagents}

Cyclic voltammetry was achieved in CHI-660c potentiostat an analytical system model (Electrochemical workstation, USA). The conventional three electrode electrochemical cell consist of a saturated calomel electrode (SCE) which act as reference electrode while platinum wire as a counter electrode and bare Carbon Paste Electrode $\mathrm{CuCrO}_{4}$ composites modified Carbon Paste Electrode as working electrode. A digital $\mathrm{pH}$ meter MK VI (Systronics) employed for the $\mathrm{pH}$ measurements. All potentials were given against SCE at $25 \pm 0.5^{\circ} \mathrm{C}$. PC was procured from Himedia and the stock solution of PC $(2.5 \mathrm{mM})$, and they were prepared in doubly distilled water. Graphite powder was bought from Lobo and silicon oil (as binder) was bought from sigma Aldrich. All chemicals were of AR grade. For buffer solution preparation, the chemicals were bought from Merck. 0.2M PBS was prepared by adding standard stock solutions $\mathrm{NaH}_{2} \mathrm{PO}_{4} \cdot \mathrm{H}_{2} \mathrm{O}(0.2 \mathrm{M})$ and $\mathrm{Na}_{2} \mathrm{HPO}_{4},(0.2 \mathrm{M})$. All the solutions were prepared freshly prior to be analysis.

\subsection{Preparation of bare carbon paste electrode (BCPE)}

BCPE was prepared by adding graphite powder (70\%) and silicone oil (30\%) and hand mixing this mixture in a agate mortar for 45 mins till to get a uniform paste. Then paste 
is poured to Poly Vinyl Chloride tube cavity and made smooth on a rubbing paper. A copper wire was used at the end of tube for the electrical connection.

\subsection{Preparation of Copper (II) Chromate nanoparticles $\left(\mathrm{CuCrO}_{4} \mathrm{NPs}\right)$}

The $\mathrm{CuCrO}_{4} \mathrm{NPs}$ were prepared through hydrothermal approach. For that, the copper chloride $\left(\mathrm{CuCl}_{2}\right)$ and potassium chromate $\left(\mathrm{K}_{2} \mathrm{CrO}_{4}\right)$ taken in the ration 1:1 and dissolved in deionized water $(50 \mathrm{~mL})$. Then, $0.7 \mathrm{~g} \mathrm{NaOH}$ was added and sonicated for 3 hrs consequently, later mixture was poured to Teflon-autoclave and maintained at $210{ }^{\circ} \mathrm{C}$ for $20 \mathrm{hrs}$. Final products were parted using centrifugation and allowed for drying at $60{ }^{\circ} \mathrm{C}$. Further, centrifugation removes powders from solution and washed with deionised water and methanol and dried at $100{ }^{\circ} \mathrm{C}$ for $24 \mathrm{hrs}$ to obtain $\mathrm{CuCrO}_{4} \mathrm{NPs}$.

\subsection{Preparation of $\mathrm{CuCrO}_{4} \mathrm{NPs}$ composite $\mathrm{MCPE}$}

The $\mathrm{CuCrO}_{4}$ NPs MCPE were synthesized by adding 30\% silicon oil and $70 \%$ graphite powder and different amounts of $\mathrm{CuCrO}_{4} \mathrm{NPs}$ from $2 \mathrm{mg}$ to $8 \mathrm{mg}$ in an agate mortar till it results a uniform paste. Resulted paste was crammed firmly to electrode cavity and then refined the surface by tissue paper.

\section{Results and Discussion}

\subsection{The XRD pattern of Carbon/ $\mathrm{CuCrO}_{4} \mathrm{NPs}$}

The XRD patterns of Carbon/ $\mathrm{CuCrO}_{4}$ powders are presented in Fig. 1. It shows that the typical peaks of $\mathrm{CuCrO}_{4}$, corresponding to the (211), (202), (112), (200), (303), (400) and (224) faces of the hexagonal structure appear in both patterns at 35.31, 37.91, 31.31, 29.81, $56.41,61.71$ and 65.01, respectively 


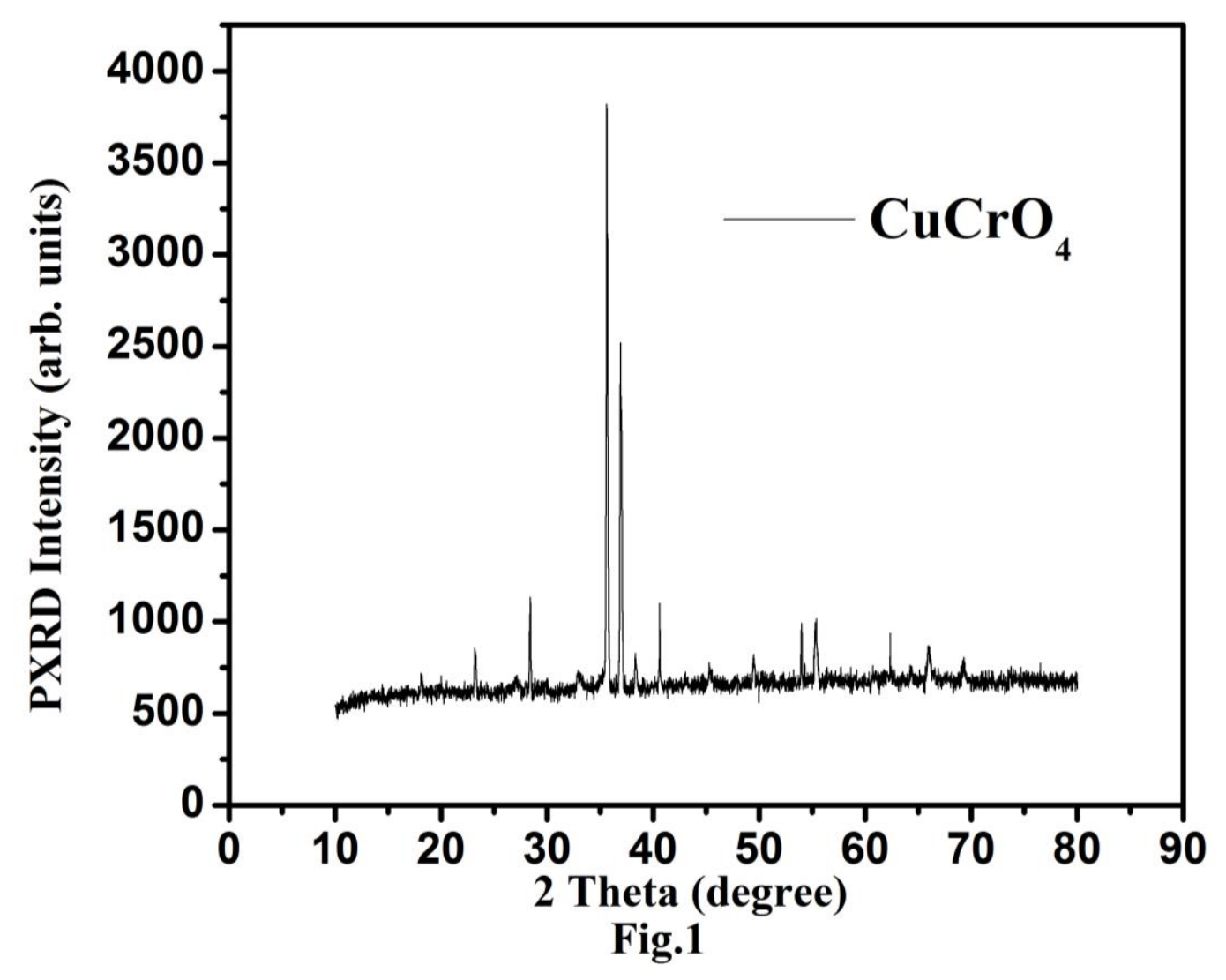

Fig.1- XRD pattern of Carbon/CuCrO 4 NPs

\subsection{Effect of $\mathrm{CuCrO}_{4} \mathrm{NPs}$ as a modifier towards the detection of PC}

$\mathrm{CuCrO}_{4} \mathrm{NPs}$ have been used as a modifier in the preparation of $\mathrm{CuCrO}_{4} \mathrm{NPs}$ composite MCPE. The $\mathrm{CuCrO}_{4} \mathrm{NPs}$ composite MCPE was characterized by using cyclic voltammetric technique. $\mathrm{CuCrO}_{4} \mathrm{NPs}$ composite MCPE were synthesized by adding few mgs of $\mathrm{CuCrO}_{4}$ NPs. By increasing the amount of $\mathrm{CuCrO}_{4}$ NPs from 2 to $6 \mathrm{mgs}$ in the CPE, the electrochemical redox peak current $\left(\mathrm{I}_{\text {peak }}\right)$ of Potassium ferrocyanide $\left(\mathrm{K}_{4}\left[\mathrm{Fe}(\mathrm{CN})_{6}\right]\right)(1 \mathrm{mM})$ goes on increasing in Potassium Chloride $(\mathrm{KCl})(1 \mathrm{M})$ as supporting electrolyte. Further increase of $\mathrm{CuCrO}_{4} \mathrm{NPs}$ in $\mathrm{CPE}$ decreased the current signal of Potassium ferrocyanide. The Cyclic voltammograms shows different quantity of $\mathrm{CuCrO}_{4} \mathrm{NPs}_{\text {in }} \mathrm{CPE}$ showed maximum anodic current signal noticed in $6 \mathrm{mg} \mathrm{CuCrO}_{4} \mathrm{NPs}-\mathrm{MCPE}$ as shown in fig.2, therefore $6 \mathrm{mg}$ $\mathrm{CuCrO}_{4} \mathrm{NPs}$ composite MCPE was chosen as optimum for all other parameters. 


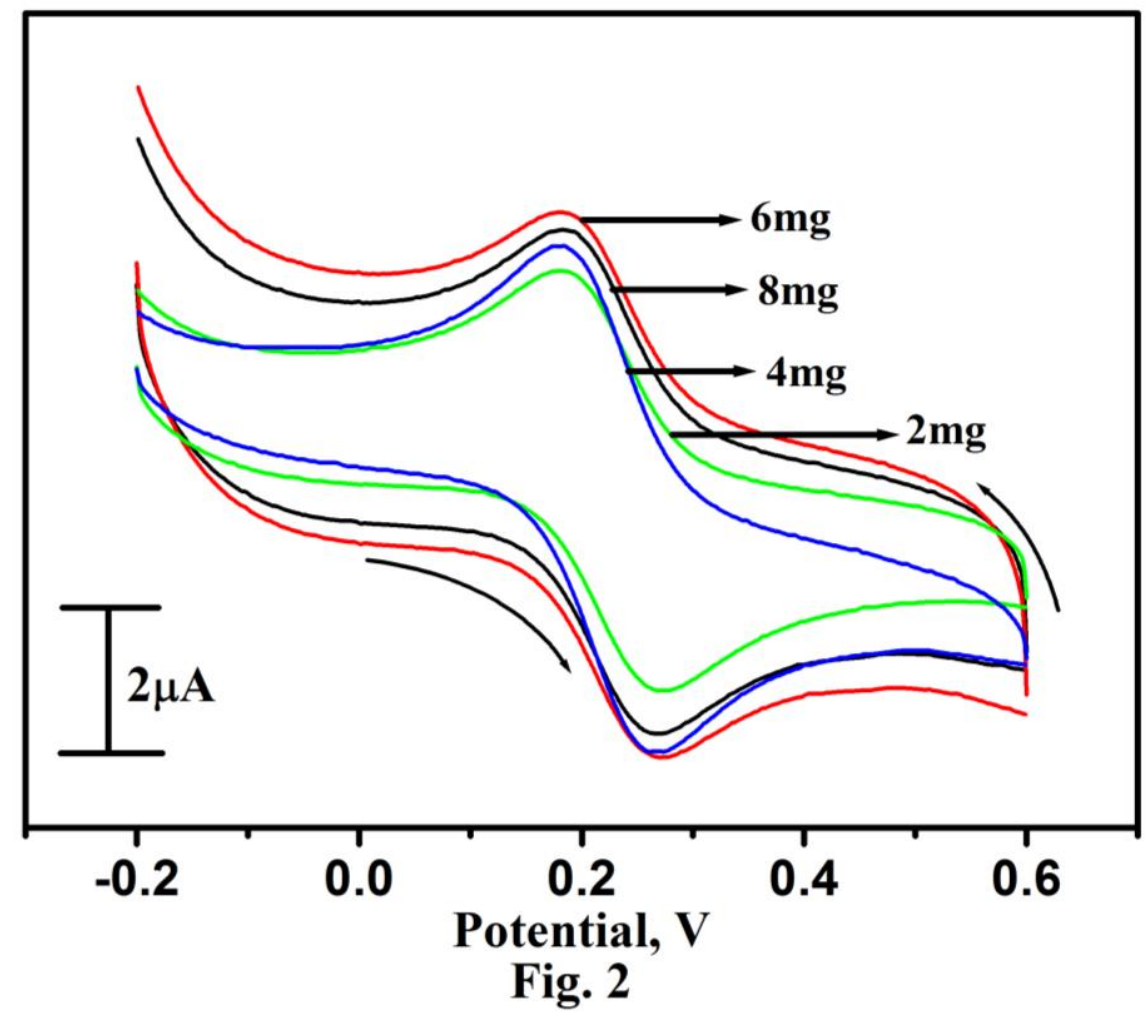

Fig.2- Cyclic Voltammograms of $\mathrm{K}_{4}\left[\mathrm{Fe}(\mathrm{CN})_{6}\right](1 \mathrm{mM})$ in $1 \mathrm{M} \mathrm{KCl}$ at different amount of $\mathrm{CuCrO}_{4} \mathrm{NPs}$ composite MCPE at scan rate of $0.1 \mathrm{~V} / \mathrm{s}$.

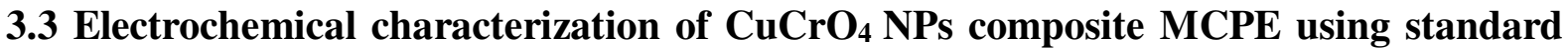 $\mathrm{K}_{4}\left[\mathrm{Fe}(\mathrm{CN})_{6}\right]$}

The supporting electrolyte (i.e., newly prepared $\mathrm{K}_{4}\left[\mathrm{Fe}(\mathrm{CN})_{6}\right]$ solution $(1 \mathrm{mM})$ in $1 \mathrm{M}$ $\mathrm{KCl}$ took in an electrochemical cell. The Fig.3 represents the voltammograms of $\mathrm{K}_{4}\left[\mathrm{Fe}(\mathrm{CN})_{6}\right]$ at both $\mathrm{BCPE}$ (i.e., dashed line) and $\mathrm{CuCrO}_{4} \mathrm{NPs}$ composite MCPE (i.e., solid line). Owing to the lethargic electron transfer kinetics, low redox $\mathrm{I}_{\text {peak }}$ response was observed at BCPE. Nevertheless, under same conditions, the $\mathrm{CuCrO}_{4} \mathrm{NPs}$ composite MCPE revealed a static rise in redox peak currents, which is due to improvisation of electron transfer kinetics. It indicates that the the modified electrode has brought considerable change in the surface properties as

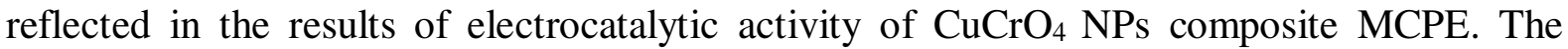
Randles-Sevcik equation (1) could be used to calculate the available surface area for species reaction in solution [29-31]. 


$$
\mathrm{Ip}=2.69 \times 10^{5} \mathrm{n}^{3 / 2} \mathrm{~A} \mathrm{D}^{1 / 2} \mathrm{C}_{0} \mathrm{v}^{1 / 2}
$$

where, $\mathrm{I}_{\mathrm{p}}$; peak current, $\mathrm{C}_{0}$; electroactive species concentration, $\mathrm{n}$; number of electrons, D; diffusion coefficient, v; scan rate and A; electroactive surface area. For $\mathrm{CuCrO}_{4}$ NPs composite MCPE the electroactive surface area was found to be maximum (i.e., 0.03522 $\mathrm{cm}^{2}$ ) when compared to BCPE (i.e., $0.02829 \mathrm{~cm}^{2}$ ).

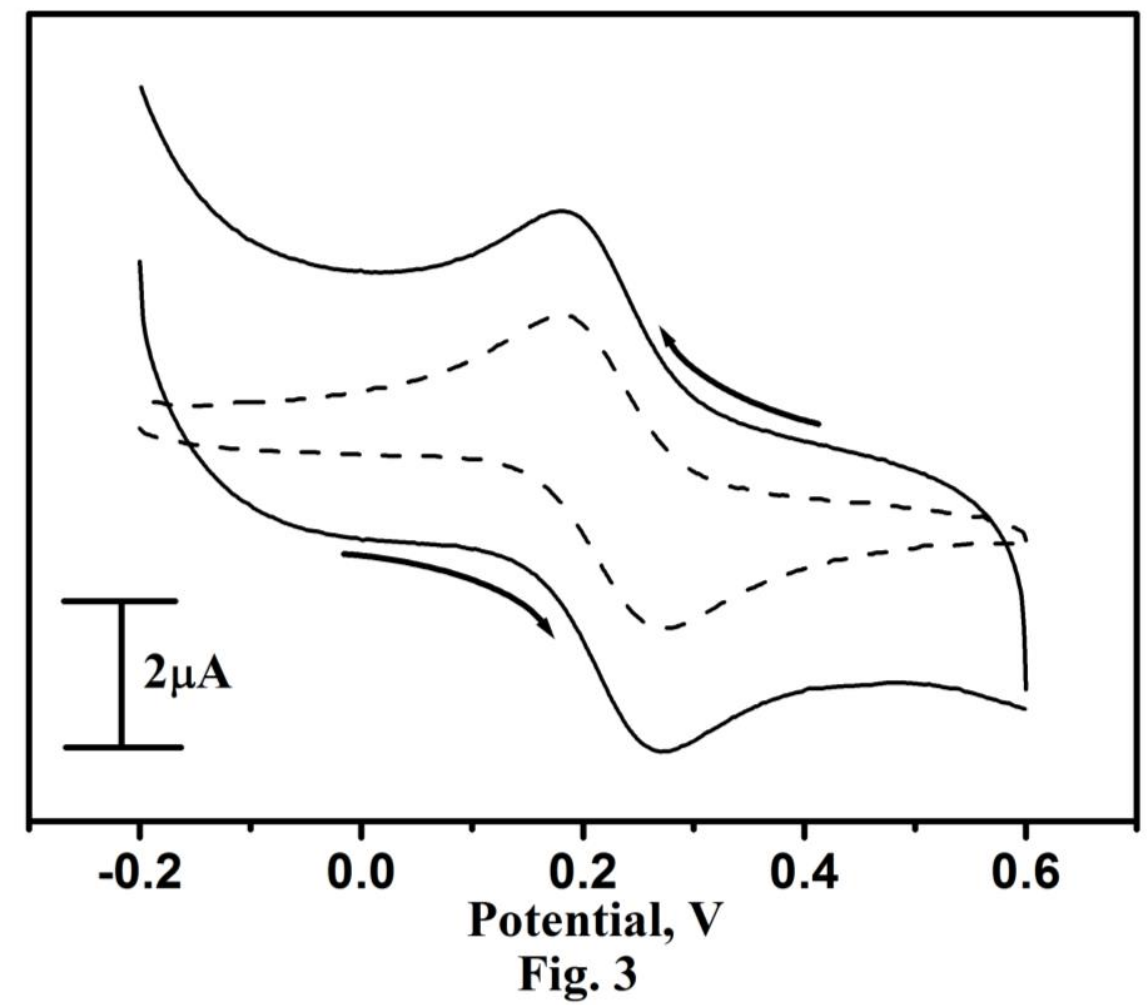

Fig.3 Voltammograms of $1.0 \mathrm{mM} \mathrm{K}_{4}\left[\mathrm{Fe}(\mathrm{CN})_{6}\right]$ in $1 \mathrm{M} \mathrm{KCl}$ solution at $\mathrm{BCPE}$ (dashed line) and $\mathrm{CuCrO}_{4} \mathrm{NPs}$ composite MCPE (solid line) at scan rate of $0.05 \mathrm{~V} / \mathrm{s}$.

\subsection{Electrochemical response of $\mathrm{PC}$ at $\mathrm{CuCrO}_{4} \mathrm{NPs}_{\text {composite } \mathrm{MCPE}}$}

Fig.4 represents voltammograms for the oxidation of $10 \mu \mathrm{M}$ PC at BCPE (dotted line) and $\mathrm{CuCrO}_{4} \mathrm{NPs}$ composite MCPE (solid line) in 0.2M PBS. At BCPE, redox $\mathrm{I}_{\text {peak }}$ response of PC was observed to be very poor with Epa $=349 \mathrm{mV}$ (anodic peak potential) and Epc $=$ $174 \mathrm{mV}$ (cathodic peak potential). The $\mathrm{CuCrO}_{4}$ composite NPs MCPE depicts significant enhanced response of $\mathrm{I}_{\text {peak }}$ for PC with $(\mathrm{Epa}=333 \mathrm{mV})$ and $(\mathrm{Epc}=177 \mathrm{mV})$. Therefore, PC 
depicts reversible process with improvement of $I_{\text {peak }}$ and sharp peak potential observed at $\mathrm{CuCrO}_{4}$ NPs composite MCPE.

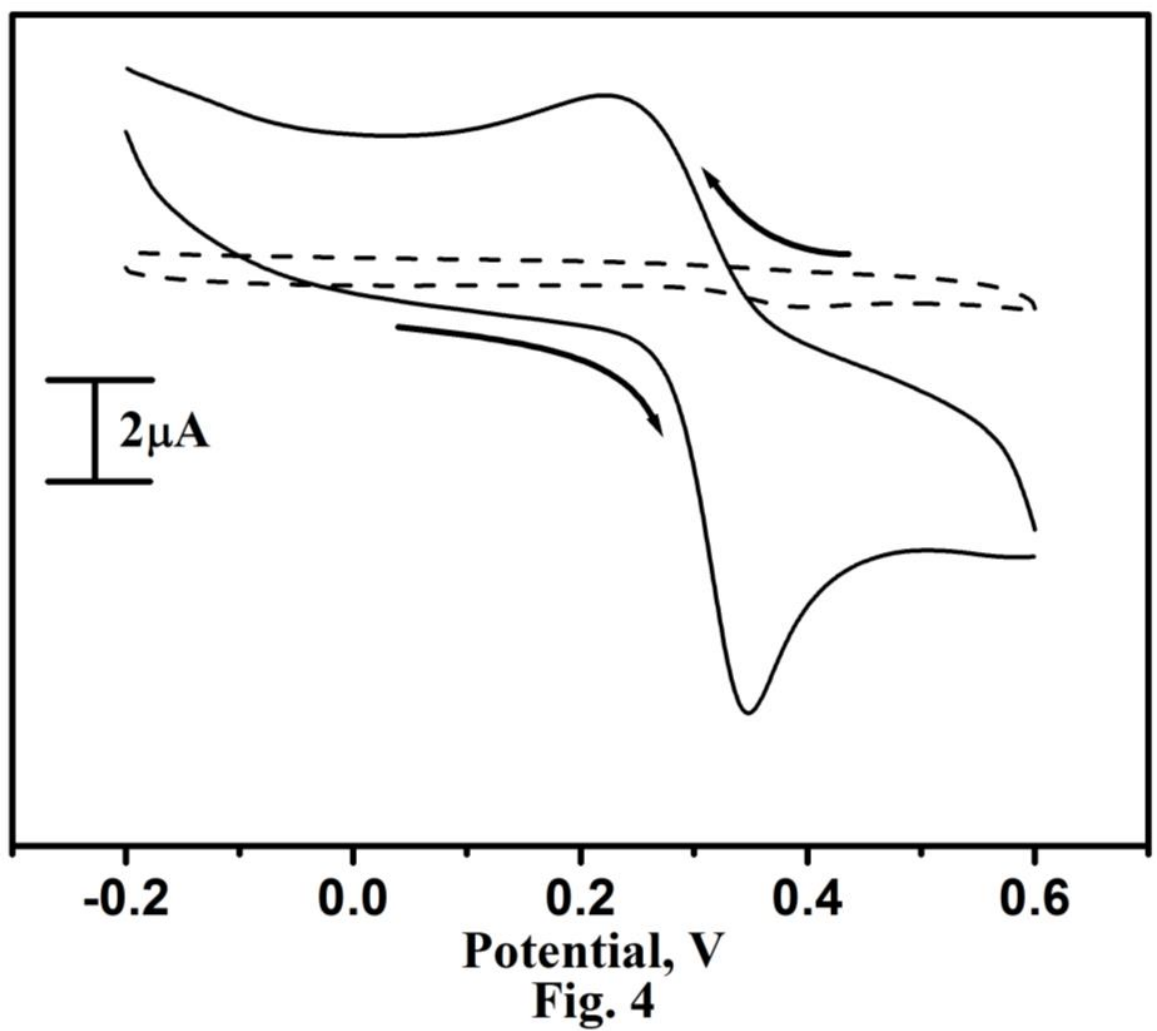

Fig.4- Voltammograms of $10 \mu \mathrm{M}$ PC in $0.2 \mathrm{M}$ PBS of pH 7.4 at BCPE (dotted line) and $\mathrm{CuCrO}_{4} \mathrm{NPs}$ composite MCPE (solid line) at scan rate of $0.05 \mathrm{~V} / \mathrm{s}$.

\subsection{Effect of scan rate on peak current of PC}

The scan rate effect for $10 \mu \mathrm{M}$ PC in $0.2 \mathrm{M}$ PBS was examined by cyclic voltammetry at $\mathrm{CuCrO}_{4} \mathrm{NPs}$ composite MCPE depicted in Fig. 5. The changed scan rate displays a reflective effect on the redox $I_{\text {peak }}$, shows that the redox $I_{\text {peak }}$ regularly enhances with increment in the scan rate i.e., from 0.05 to $0.5 \mathrm{~V} / \mathrm{s}$ and proportional to each other according to Randles Sevcik eqn. The $\mathrm{E}_{\mathrm{pa}}$ changed partly towards positive direction while $\mathrm{E}_{\mathrm{ca}}$ towards negative direction. The graph of $\log \mathrm{I}_{\mathrm{pa}}$ of $\mathrm{PC}$ v/s logv was plotted for $\mathrm{CuCrO}_{4} \mathrm{NPs}$ composite MCPE and the slope obtained was 0.55 therefore the electrode process was controlled by diffusion [32] as shown in Fig.6. From the graph, it shows a good linearity between anodic 
$\mathrm{I}_{\text {peak }}$ and scan rates. It showed an excellent linearity for $\mathrm{CuCrO}_{4} \mathrm{NPs}$ composite $\mathrm{MCPE}$ i.e., $\left(\log I_{p a}\right)=0.55940(\operatorname{logv})+4.8669$ with $\left(r^{2}=0.9991\right)$.

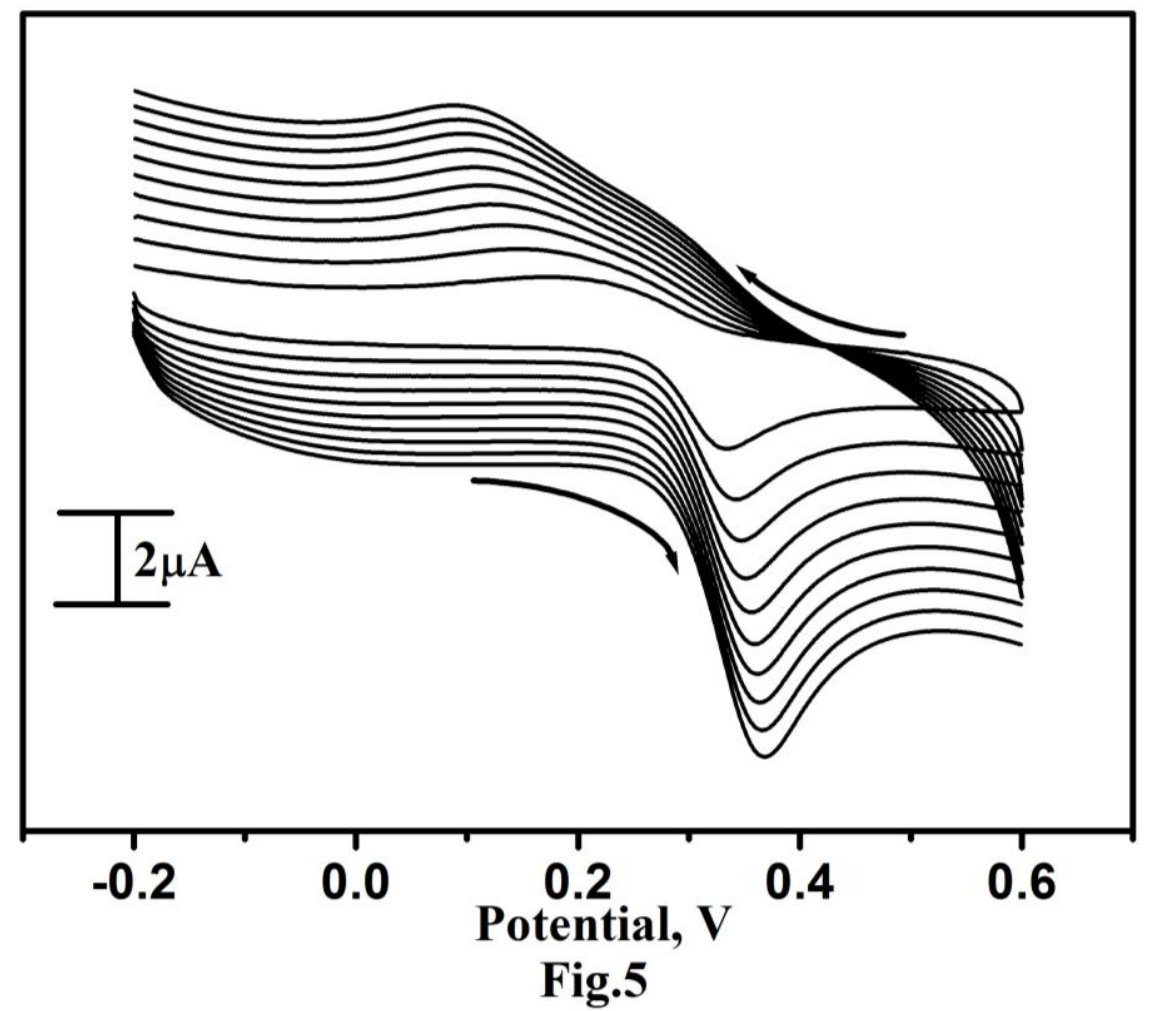

Fig.5- Voltammograms of $10 \mu \mathrm{M}$ PC in $0.2 \mathrm{M}$ PBS of $\mathrm{pH} 7.4$ at $\mathrm{CuCrO}_{4} \mathrm{NPs}$ composite MCPE at different scan rate from $0.05 \mathrm{~V} / \mathrm{s}$ to $0.5 \mathrm{~V} / \mathrm{s}$ ). 


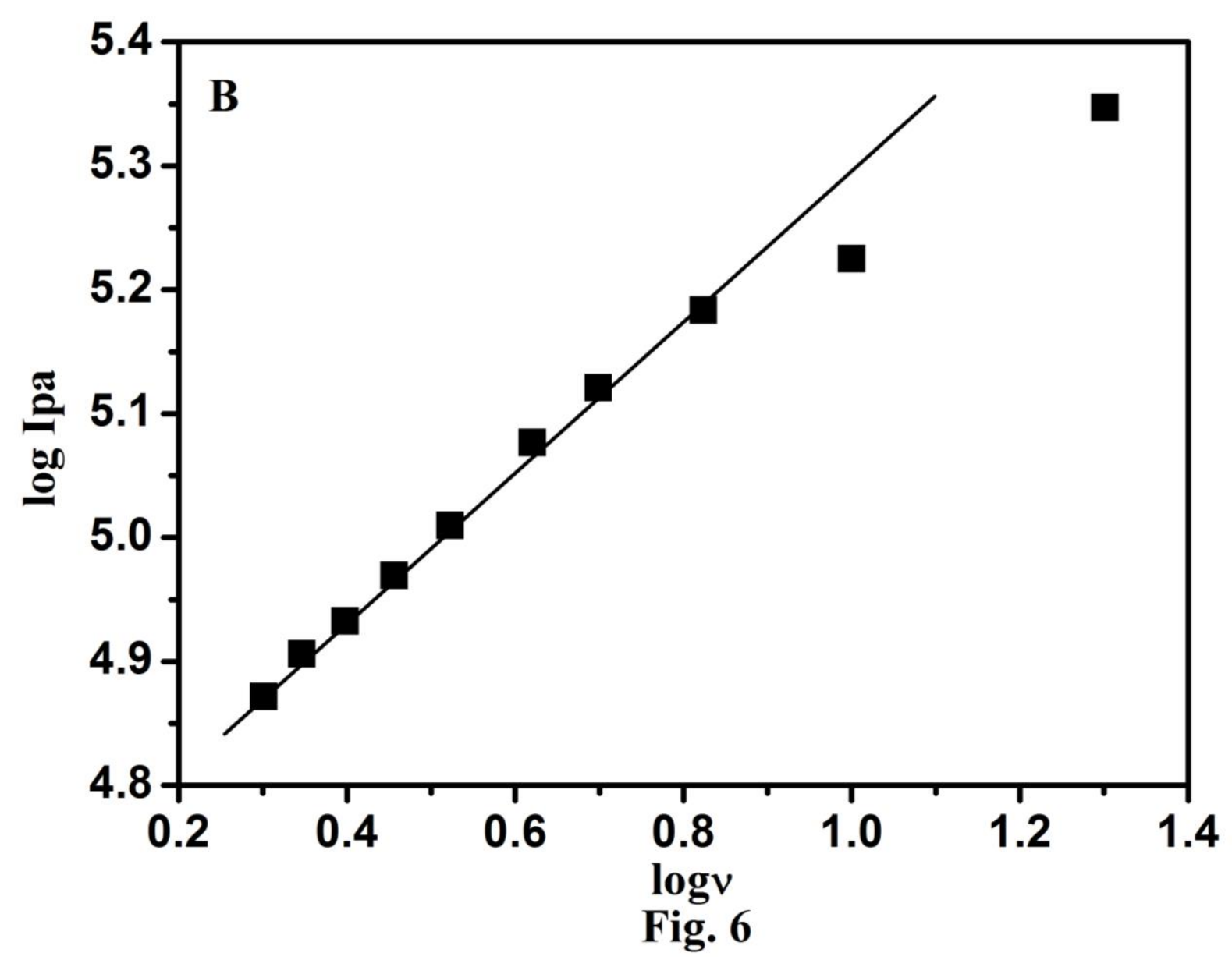

Fig.6 - Graph of $\log \mathrm{I}_{\mathrm{pa}}$ of PC versus logv.

\subsection{Effect of concentration}

Fig.7 shows voltammograms at different concentrations of PC. The PC concentration diverse from 2 to $12 \mu \mathrm{L}$ in PBS $(0.2 \mathrm{M})$ at scan rate of $0.05 \mathrm{~V} / \mathrm{s}$ for $\mathrm{CuCrO}_{4} \mathrm{NPs}$ composite MCPE. It is comprehensible that as PC concentration increases, the $\mathrm{I}_{\mathrm{pa}}$ and $\mathrm{I}_{\mathrm{pc}}$ also increases with shift in $\mathrm{E}_{\mathrm{pa}}$ and $\mathrm{E}_{\mathrm{pc}}$ towards less negative potential and positive potential, respectively. Graph of $\mathrm{I}_{\mathrm{pa}}$ of PC v/s PC concentration, displays enhancement in redox Ipeak at $\mathrm{CuCrO}_{4}$ NPs composite MCPE. It is almost good linearity with straight line shows in Fig.8. Linear regression equation for $\mathrm{PC}$ at $\mathrm{CuCrO}_{4}$ NPs composite $\mathrm{MCPE}$ gives $\mathrm{I}_{\mathrm{pa}}(\mu \mathrm{A})=0.1562\left(\mathrm{C}_{0}\right.$ $\mu \mathrm{M} / \mathrm{L})+2.698 \times 10^{-7}$ and correlation co-efficient $\left(\mathrm{r}^{2}\right)$ value is 0.9953 . This revealed that good linearity and quantification limit (LQ). The detection limit (LD) was computed using the equations ( $2 \& 3)$ [33-36]. 


$$
\begin{aligned}
& \mathrm{LQ}=10 *(\mathrm{~S} / \mathrm{M}) \\
& \mathrm{LD}=3^{*}(\mathrm{~S} / \mathrm{M})
\end{aligned}
$$

Where, S; standard deviation and M; slope from the graph. The LD and LQ values for PC were $1.21 \mu \mathrm{M}$ and $4.04 \mu \mathrm{M}$, respectively at $\mathrm{CuCrO}_{4} \mathrm{NPs}$ composite MCPE. It is clear that the prepared $\mathrm{CuCrO}_{4} \mathrm{NPs}$ composite MCPE observed good linearity and low LD and LQ values.

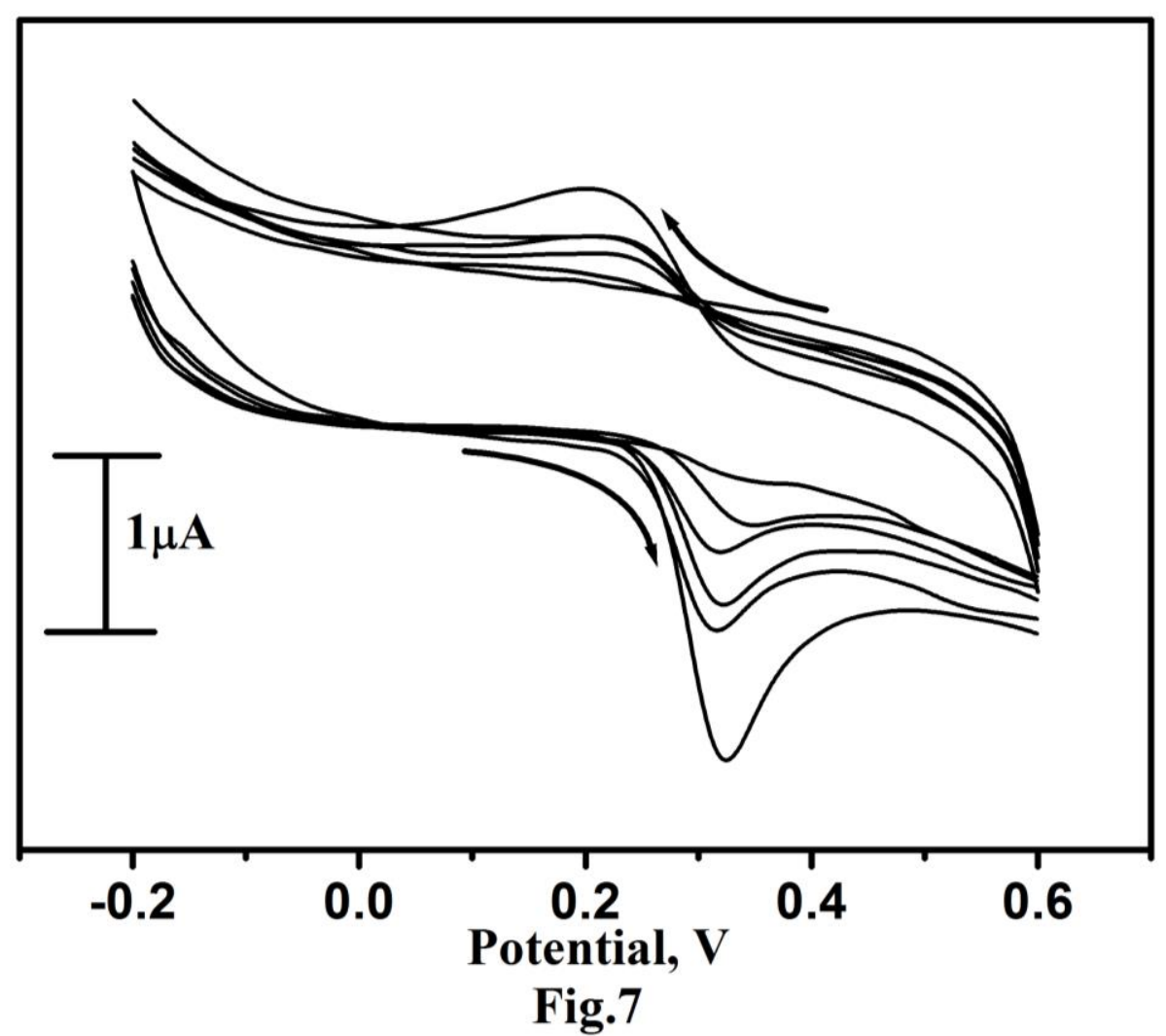

Fig.7 -Voltammograms of PC in 0.2M PBS of $\mathrm{pH} 7.4$ at $\mathrm{CuCrO}_{4}$ NPs composite MCPE with different concentration from 2 to $12 \mu \mathrm{L}$. 


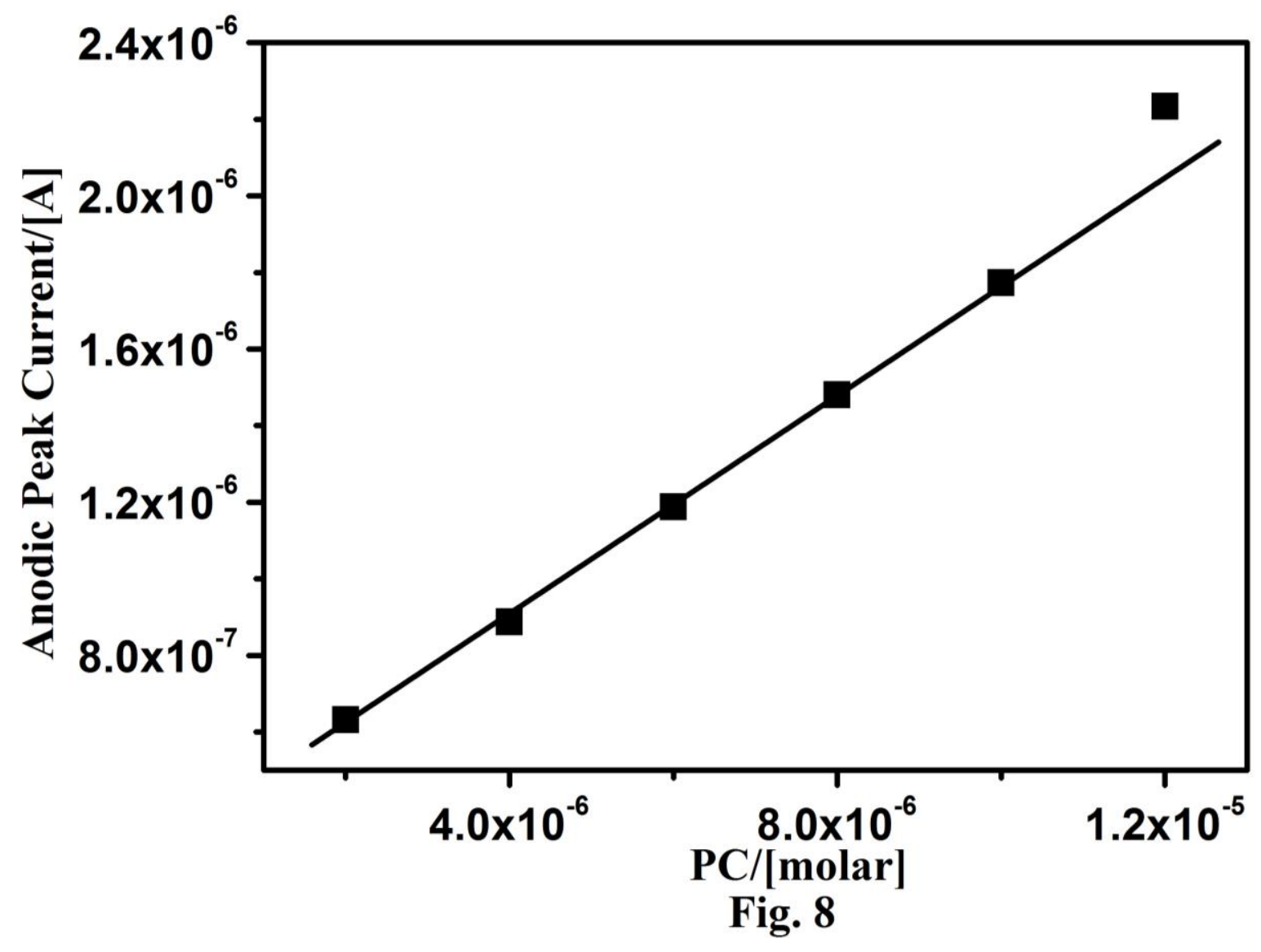

Fig.8- Graph of anodic $\mathrm{I}_{\text {peak }} \mathrm{v} / \mathrm{s}$ PC concentration

\subsection{Effect of solution $\mathrm{pH}$}

PC is an easily oxidizable electroactive drug. The CV studies were carried out to examine the supporting electrolyte effect on electrochemical oxidation of $\mathrm{PC}$ at $\mathrm{CuCrO}_{4} \mathrm{NPs}$ composite MCPE. The Fig.9 represents the voltammograms of $10 \mu \mathrm{M}$ PC in $0.2 \mathrm{M}$ PBS at various $\mathrm{pH}(6.2$ to 7.8$)$ at scan rate of $0.05 \mathrm{~V} / \mathrm{s}$ at $\mathrm{CuCrO}_{4} \mathrm{NPs}$ composite MCPE. $\mathrm{I}_{\mathrm{pa}}$ and $\mathrm{I}_{\mathrm{ca}}$ initially from 6.2 to 7.0 decreases, then from 7.0 to 7.4 increases after words it decreases with increases from 7.4 to 7.8 . The $\mathrm{I}_{\mathrm{pa}}$ and $\mathrm{I}_{\mathrm{ca}}$ were shifted towards negative direction with increment in $\mathrm{pH}$ from 6.2 to 7.8 . A shift in $\mathrm{E}_{\mathrm{pa}} 0.45 \mathrm{~V}$ to $0.35 \mathrm{~V}$ was observed for $\mathrm{PC}$ oxidation at $\mathrm{CuCrO}_{4} \mathrm{NPs}$ composite MCPE with $\mathrm{pH}$ from 6.2 to 7.8 . But the $\mathrm{pH} 7.4$ was the physiological $\mathrm{pH}$ therefore it was chosen for all the studies. The potential figure was put up by the plot of Epa v/s different values $\mathrm{pH}$ (Fig.10). The results afford from linear equation with the slope of $43 \mathrm{mV} / \mathrm{pH}\left(\mathrm{r}^{2}=0.998\right)$ at $\mathrm{CuCrO}_{4} \mathrm{NPs}$ composite MCPE [37]. All this 
indicates that during electrochemical reaction of $\mathrm{PC}$, the process of electrode where, exchange of electron is considerably affected by protons and electrons. From the slope, it is confirmed that the number of exchanged electrons and protons were same. This study exposes that electrochemical oxidation of $\mathrm{PC}$ at $\mathrm{CuCrO}_{4} \mathrm{NPs}$ composite $\mathrm{MCPE}$ was $\mathrm{pH}$ dependent process and $\mathrm{CuCrO}_{4} \mathrm{NPs}$ composite MCPE represents good enhancement of redox Ipeak and minimize the over potential.

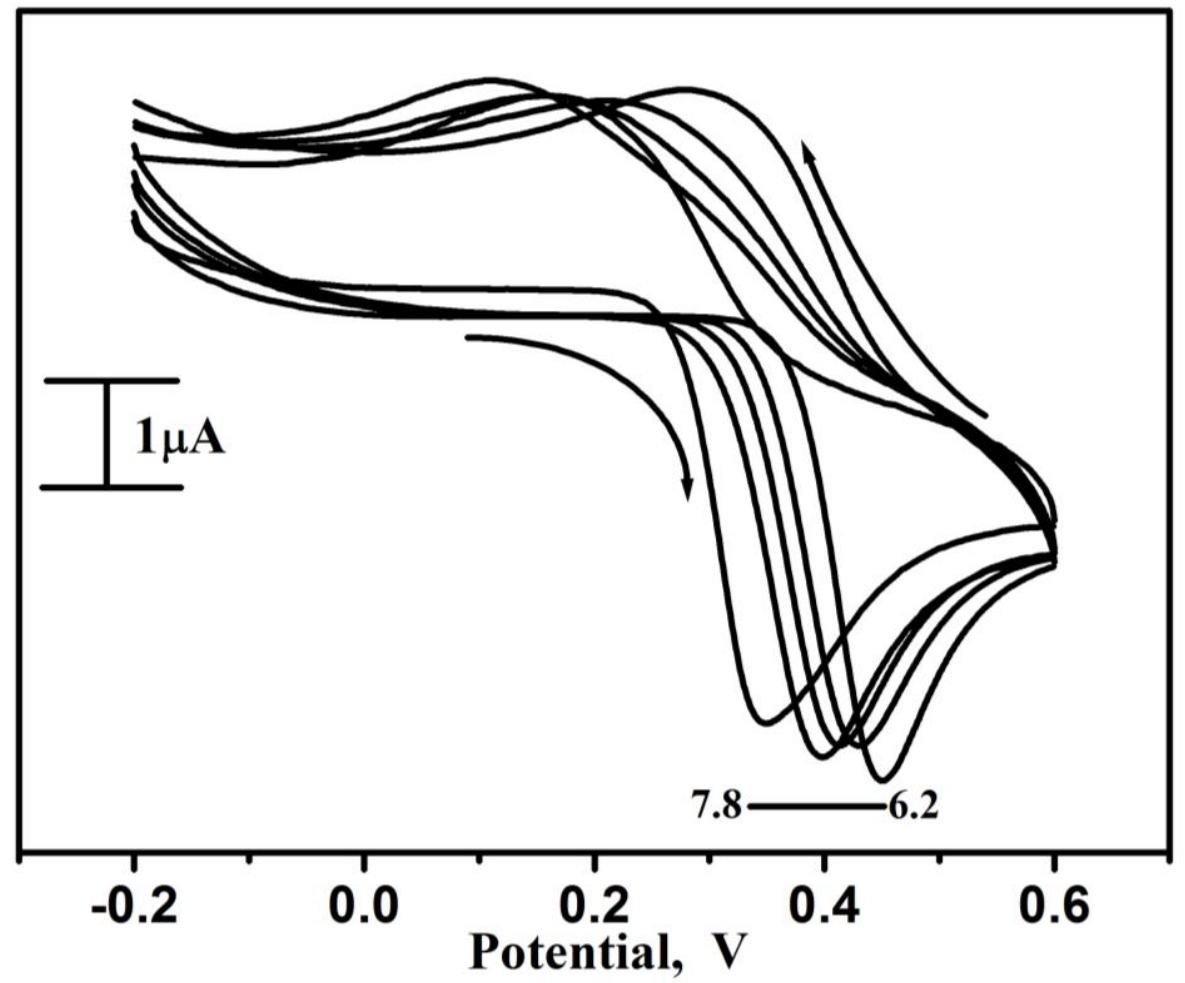

Fig. 9

Fig.9-Cyclic voltammograms of oxidation of $10 \mu \mathrm{M}$ PC in $0.2 \mathrm{M}$ PBS of different $\mathrm{pH}$ at $\mathrm{CuCrO}_{4} \mathrm{NPs}$ composite MCPE 


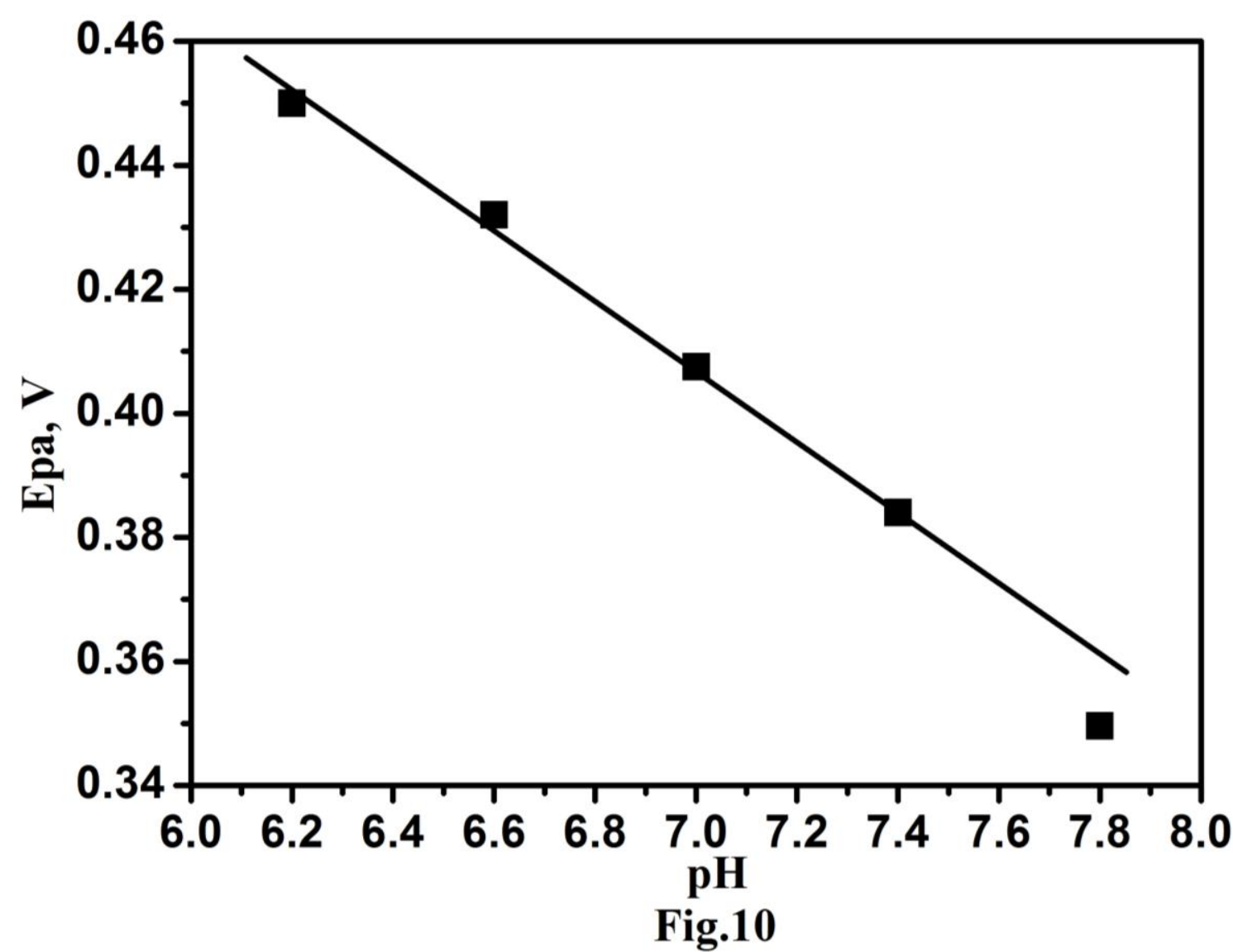

Fig.10- Graph of anodic peak potential versus $\mathrm{pH}$

\section{Conclusion}

An electrochemical sensor for PC finding was established based on the $\mathrm{CuCrO}_{4} \mathrm{NPs}$ composite MCPE. The $\mathrm{CuCrO}_{4}$-NPs homogeneously dispensed confirmed that large surface area, good conductivity and exhibited excellent catalytic activity towards the electrochemical oxidation of paracetamol. The $\mathrm{CuCrO}_{4}$-NPs composite MCPE based electrochemical sensor displayed wide linear range and significant sensitivity and it also attained a very low LD of just $1.21 \mu \mathrm{M}$. The $\mathrm{CuCrO}_{4}$ nanoparticle composite MCPE process of the electrode was controlled by diffusion. The $\mathrm{pH}$ studies shows equal number of electrons and protans engaged in the the electrochemical oxidation of paracetamol. 


\section{Acknowledgment}

The author, S. R. Priyanka hereby acknowledges that she has the financial assistance for her

Ph. D research from "National Fellowship \& Scholarship for higher education of ST students" for the year 2017-18 and Ref. No: 201718-NFST-KAR-02320.

\section{References}

1. T. Liu, L. Wang, P.Yang, B. Hu, J.Mater.Lett. (2008) https://doi.org/10.1016/j.matlet.2008. 04.081.

2. D. Li, X. Fang, W. Dong, Z. Deng, R. Tao, S. Zhou, J. Wang, T. Wang, Y. Zhao, X. Zhu, J. Phys. D: Appl. Phys. (2009) https://doi.org/10.1088/0022-3727/42/5/055009.

3. R. Prasad, P. Singh, J. Bull. Chem. React. Eng. Catal. (2011) https://doi.org/10.9767/bcrec.6.2.829.63-113

4. S. H. Yu, M. Yoshimura, Adv. Funct. Mater. (2002) https://doi.org/10.1002/16163028(20020418)12:4<277::AID-ADFM277>3.0.CO;2-M

5. Ce-Wen Nan, M. I. Bichurin, Shuxiang Dong, D. Viehland, G. Srinivasan, J. Appl. Phys. (2008) https://doi.org/10.1063/1.2836410.

6. J. S. Jang, S. J. Hong, J. S. Lee, Pramod H. Borse, Ok-Sang Jung, T. E. Hong, E. D. Jeong, M. S. Won and H. G. Kim, J. Korean Phys. Soc. (2009) https://doi.org/10.3938/jkps.54.204.

7. Rekha Dom, R. Subasri, K. Radha, Pramod H. Borse, Solid State Comm. (2011) https://doi.org/10.1016/j.ssc.2010.12.034.

8. W. Xiong, G.M.Kale, J. Sens. Actu. (2006) https://doi.org/10.1016/j.snb.2005.12.039.

9. R. Prasad, P. Singh, J. Bull. Chem. React. Eng. Catal. (2011) https://doi.org/10.9767/bcrec.6.2.829.63-113.

10. M. Hossein Habibi, F. Fakhri, J. Therm Anal Calorim. (2014) https://doi.org/10.1007/s10973-013-3480-x.

11. A. M. Kawamoto, L. C. Pardini, L.C. Rezende, J. Aerosp. Sci. Technol. (2004) https://doi.org/10.1016/j.ast.2004.06.010.

12. P. R. Patil, V. N. Krishnamurthy, S. S. Joshi, Propellants Explos. Pyrotech. (2008) https://doi.org/10.1002/prep.200700242

13. British Pharmacopoeia, H.M. Stationery office, London, UK, 2013, 1700.

14. M.I. Blake, L.B.Shumaker, J. Ass. Off. Analyt. Chem.,56, 653 (1973) 
15. R. Chandra, D.K. Sharma, Int. J. Chromatogr. Sci., 3, 31 (2013)

16. H. M. Adress Hasan, I. H. Habib, A. A. Khatab, Eur. Chem. Bull.(2017). http://dx.doi.org/10.17628/ecb.2017.6.330-335.

17. A.Maslarska, J. Tencheva, Int. J. Pharm and Pharm. Sci., 5, 417 (2013)

18. L.Martinez, D. Satinsky, P. Solich, O.Barrales, A. Molina, J. Pharmaceu. Biomed. Analysis. (2007) https://doi.org/10.1016/j.jpba.2007.05.004.

19. Zinati, M. S. Abdel-Lati, The Open Analytical Chemistry Journal. (2015) 10.2174/1874065001508010001.

20. J. W. Murfin, J. S. Wragg, Analyst. (1972) 10.1039/an9729700670.

21. H. Bramwell, A.E.G. Cass, P.N.B.Gibbsm, M.J. Green, Analyst. (1990) https://doi.org/10.1039/AN9901500185.

22. O.-W. Lau, S.-F. Luk, Y.P.M. Cheung, Analyst.(1989) https://doi.org/10.1039/AN9891401047

23. C.Wang, C.X.Hu, Z. Leng, G. Yang, G.Jin, Analyt. Lett. (2001) https://doi.org/10.1081/AL-100108420

24. J.-M. Zen, Y-S. Ting, Analyt. Chim. Acta.(1997) https://doi.org/10.1016/S00032670(96)00527-2

25. M.M.Vinay, Y.Arthoba Nayaka, Journal of Science Advanced Materials and Devices (2019) DOI: 10.1016/j.jsamd.2019.07.006.

26. T.S. Sunil Kumar Naik, B.E. Kumara Swamy, Praveen C. Ramamurthy, K.Chetan kumar, Materials Science for Energy Technologies. (2020) https://doi.org/10.1016/j.mset.2020.07.003.

27. E. Ivers-Tiffèe, K. H. Härdtl, W. Menesklou, J. Riegel, Electrochimica Acta.(2001) https://doi.org/10.1016/S0013-4686(01)00761-7.

28. R. Moos, International Journal of Applied Ceramic Technology.(2005) https://doi.org/10.1111/j.1744-7402.2005.02041.x.

29. S. Reddy, B. E. K. Swamy, H. Jayadevappa, Electrochim. Acta. (2012) https://doi.org/10.1016/j.electacta.2011.11.091.

30. M. Pacios, M. del Valle, J. Bartroli, M. J. Esplandiu, J. Electroanal. Chem. (2008) https://doi.org/10.1016/j.jelechem.2008.03.019. 
31. D. Salinas-Torresa, F. Huertab, F. Montillaa, E. Morallóna, Electrochim. Acta.(2011) https://doi.org/10.1016/j.electacta.2010.11.023.

32. D. K. Gosser, Cyclic Voltammetry, VHC New York, (1994)

33. A. Radi, J. Pharm. Biomed. Anal. (2003) DOI: 10.1016/s0731-7085(02)00707-0.

34. J. L. Yan, J. Appl. Sci. (2006) DOI: 10.3923/jas.2006.1625.1627

35. A. Salimi, Z. Enferadi, A. Noorbakhash, K. Rashidi, J. Solid State Electr., 16, 1369 (2012)

36. F. Belal, El. N. Enany, M. Rizk, J. Food Drug Anal. (2004)

https://doi.org/10.38212/2224-6614.2656

37. K.R. Mahanthesha and B.E. Kumara Swamy, J. Electroanal. Chem.(2013) https://doi.org/10.1016/j.jelechem.2013.05.004 
Figures

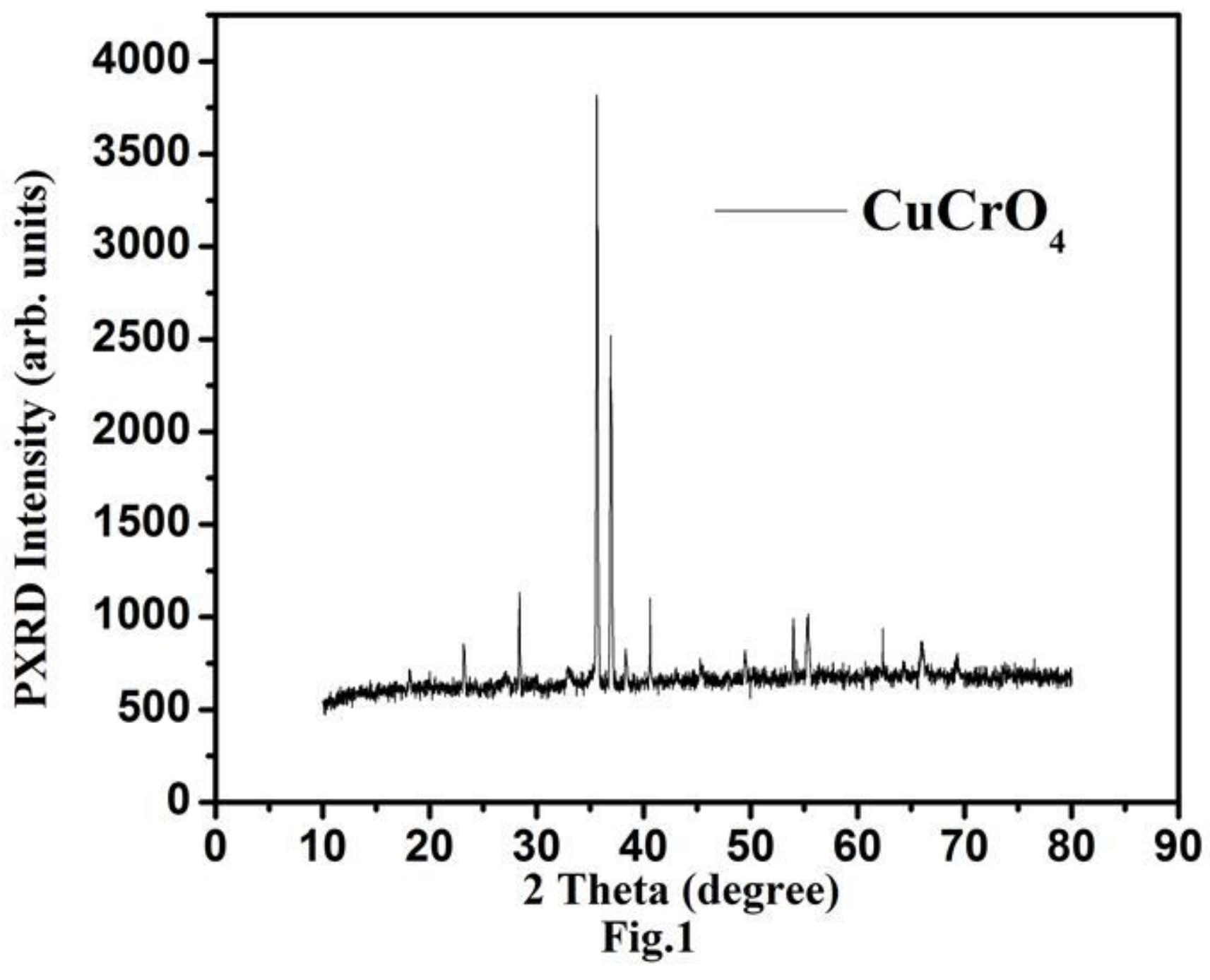

Figure 1

XRD pattern of Carbon/CuCrO4 NPs 


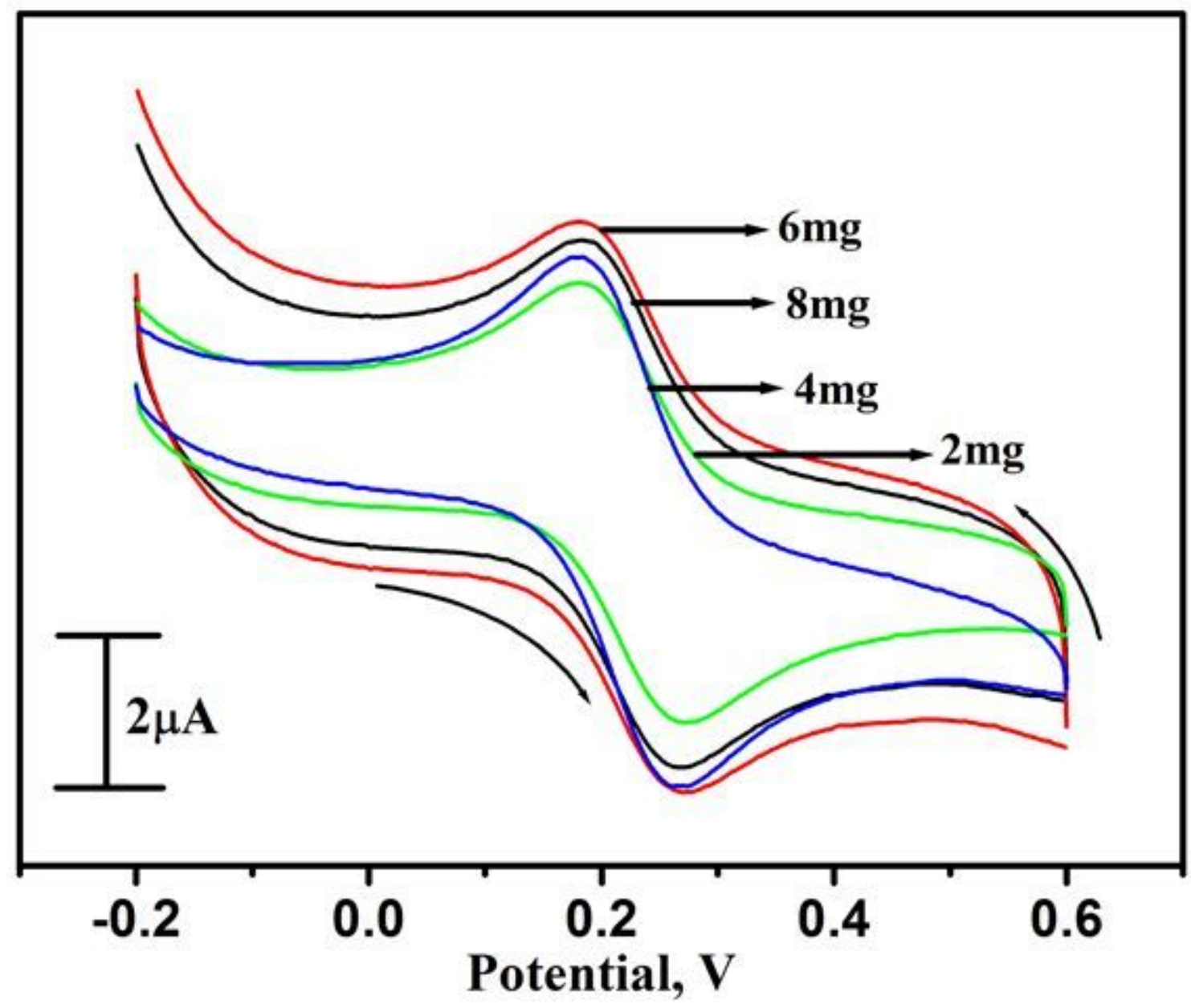

Figure 2

Cyclic Voltammograms of $\mathrm{K} 4[\mathrm{Fe}(\mathrm{CN}) 6](1 \mathrm{mM})$ in $1 \mathrm{M} \mathrm{KCl}$ at different amount of CuCrO4 NPs composite MCPE at scan rate of $0.1 \mathrm{~V} / \mathrm{s}$. 


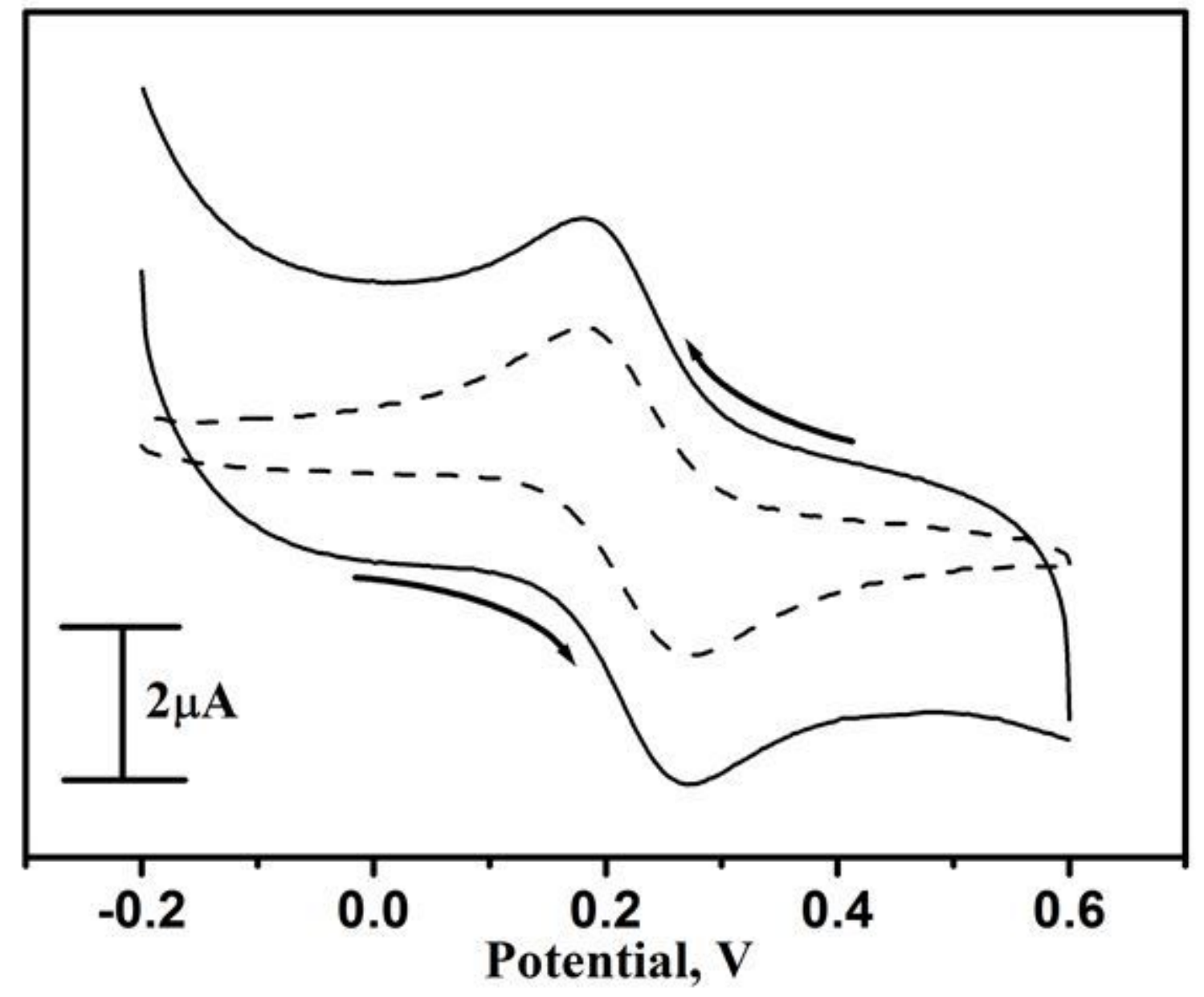

Figure 3

Voltammograms of $1.0 \mathrm{mM} \mathrm{K4}[\mathrm{Fe}(\mathrm{CN}) 6]$ in $1 \mathrm{M} \mathrm{KCl}$ solution at BCPE (dashed line) and CuCrO4 NPs composite MCPE (solid line) at scan rate of $0.05 \mathrm{~V} / \mathrm{s}$. 


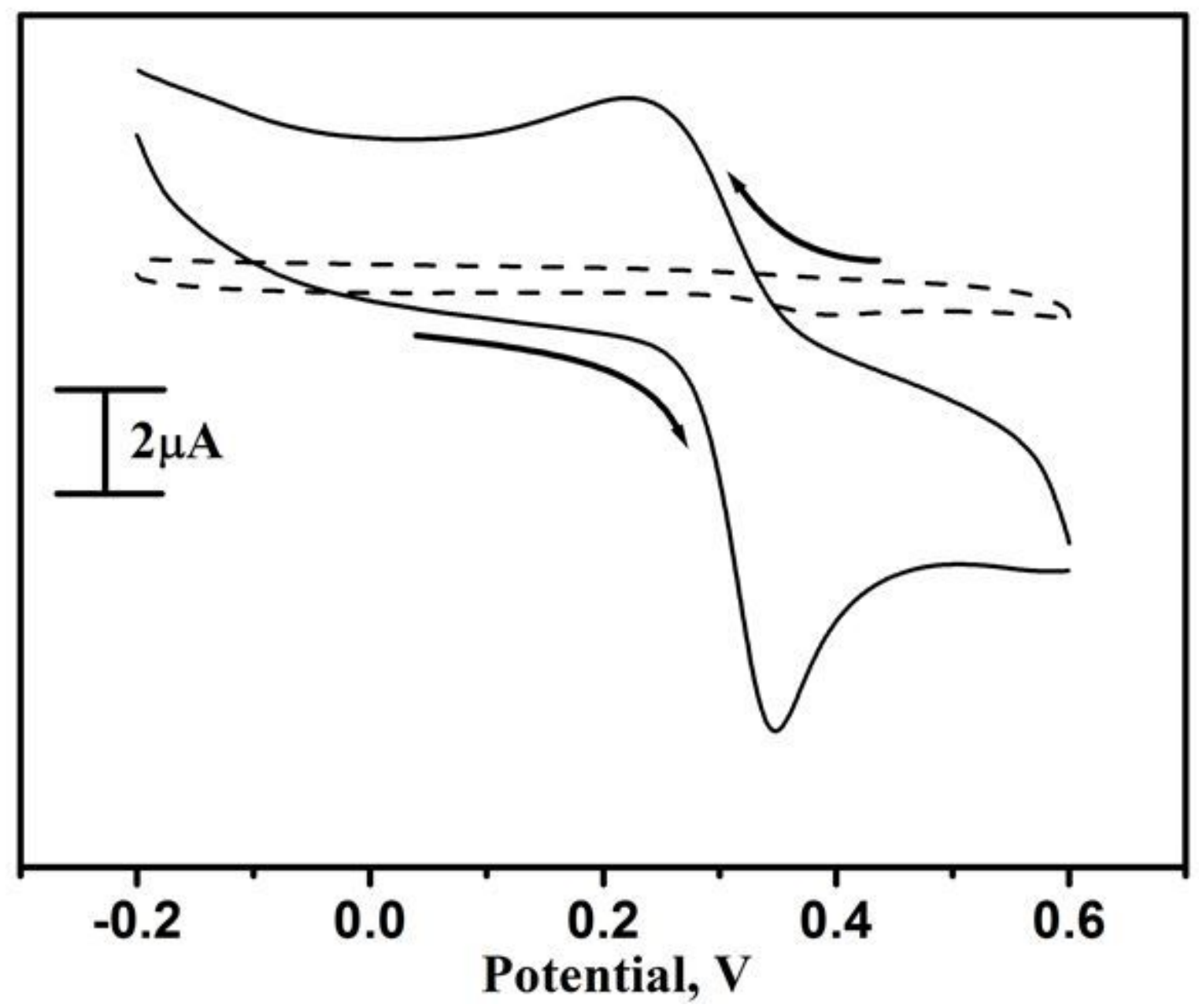

Figure 4

Voltammograms of $10 \mu \mathrm{M} \mathrm{PC}$ in $0.2 \mathrm{M}$ PBS of pH 7.4 at BCPE (dotted line) and CuCrO4 NPs composite MCPE (solid line) at scan rate of $0.05 \mathrm{~V} / \mathrm{s}$. 


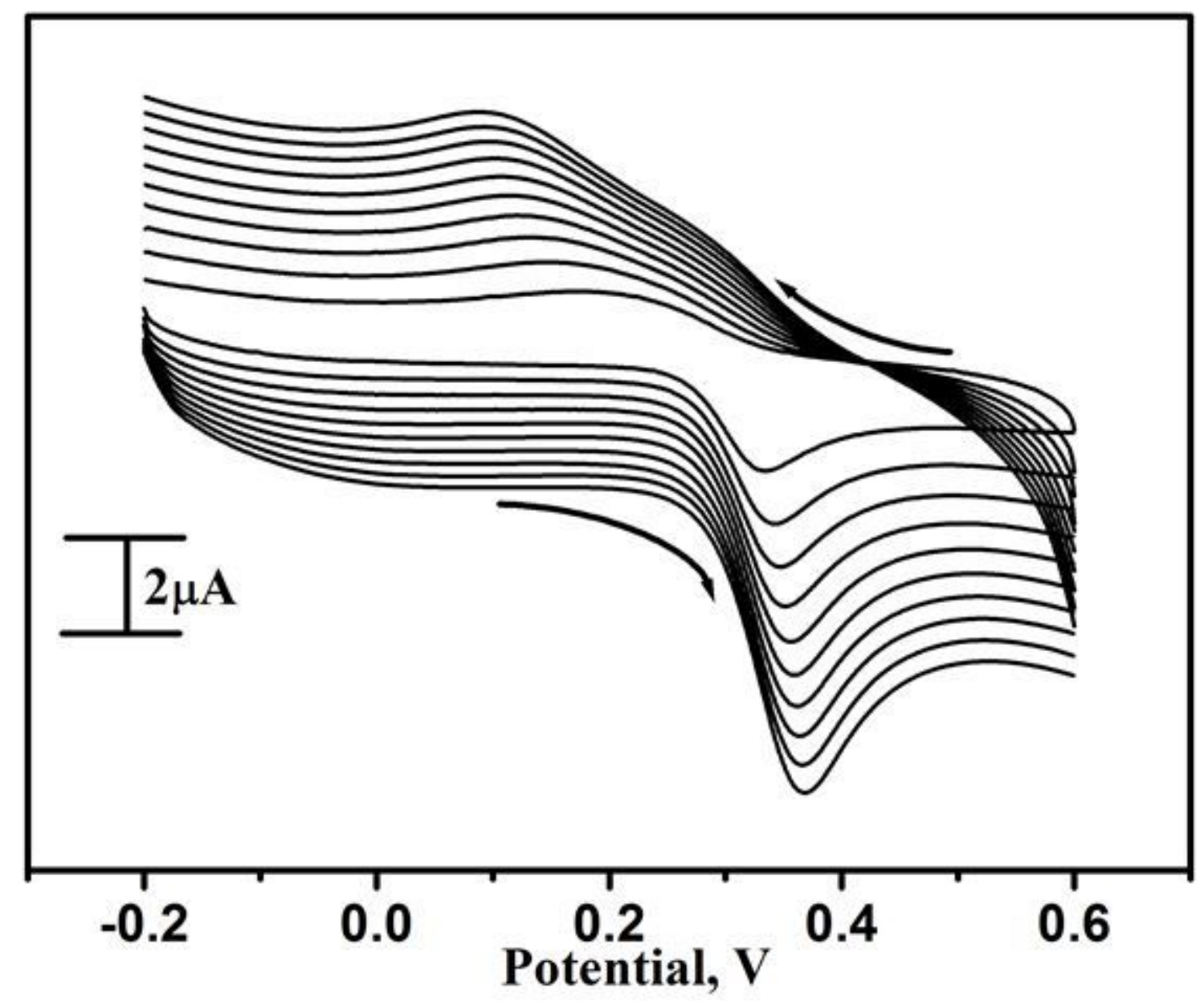

Figure 5

Voltammograms of $10 \mu \mathrm{M}$ PC in $0.2 \mathrm{M}$ PBS of $\mathrm{pH} 7.4$ at CuCrO4 NPs composite MCPE at different scan rate from $0.05 \mathrm{~V} / \mathrm{s}$ to $0.5 \mathrm{~V} / \mathrm{s}$ ). 


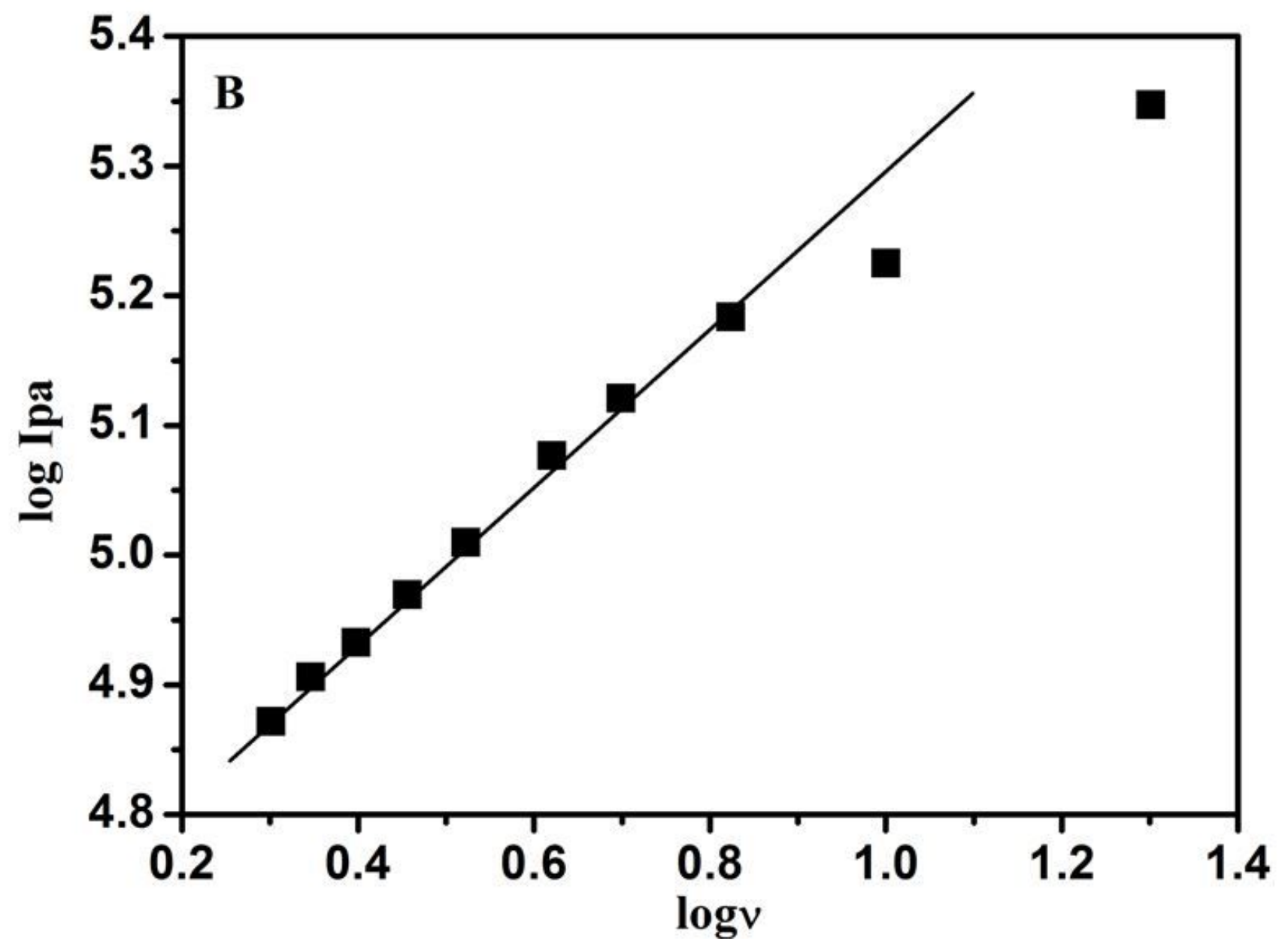

Figure 6

Graph of log Ipa of PC versus logu. 


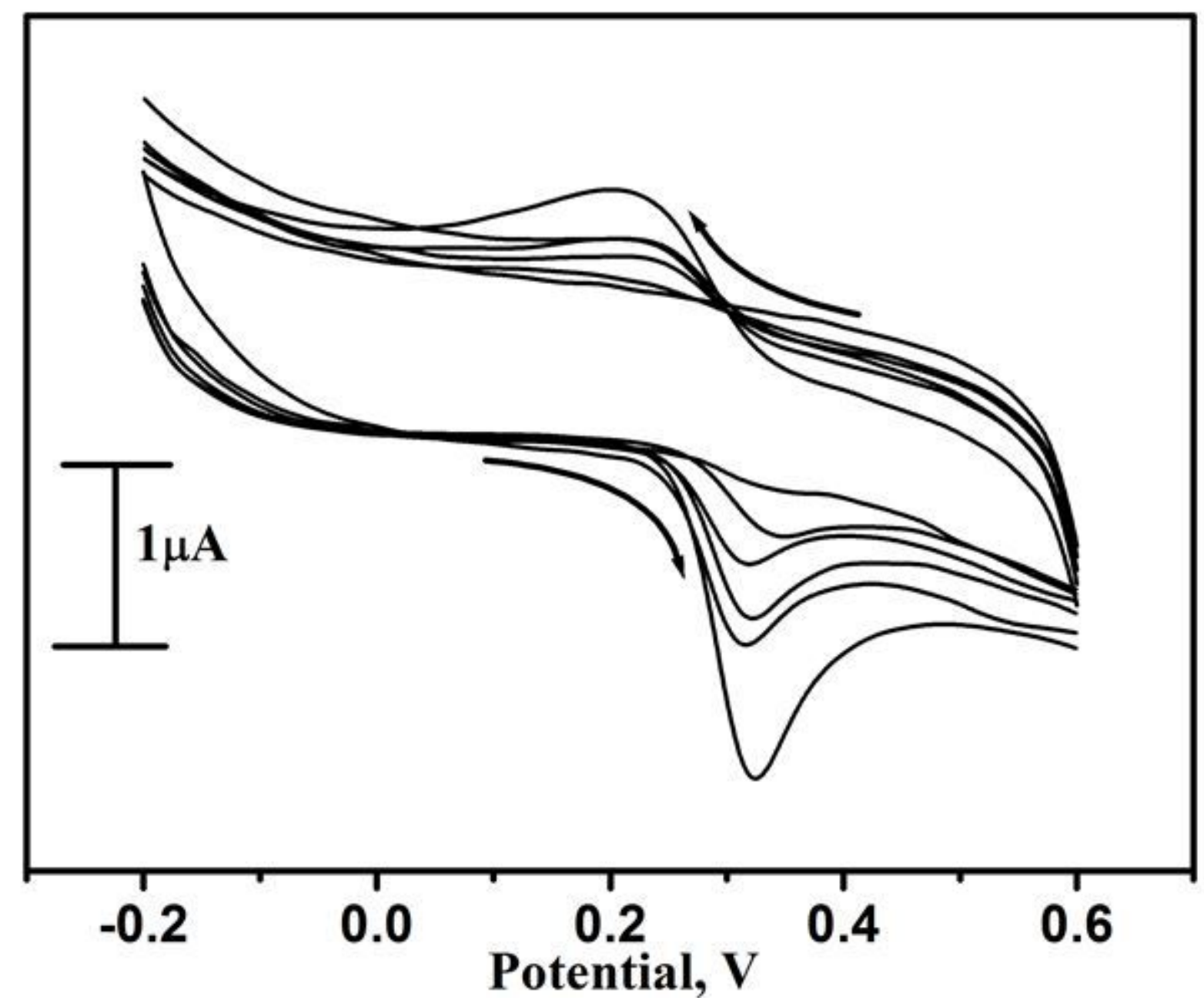

Figure 7

Voltammograms of PC in 0.2M PBS of pH 7.4 at CuCrO4 NPs composite MCPE with different concentration from 2 to $12 \mu \mathrm{L}$. 


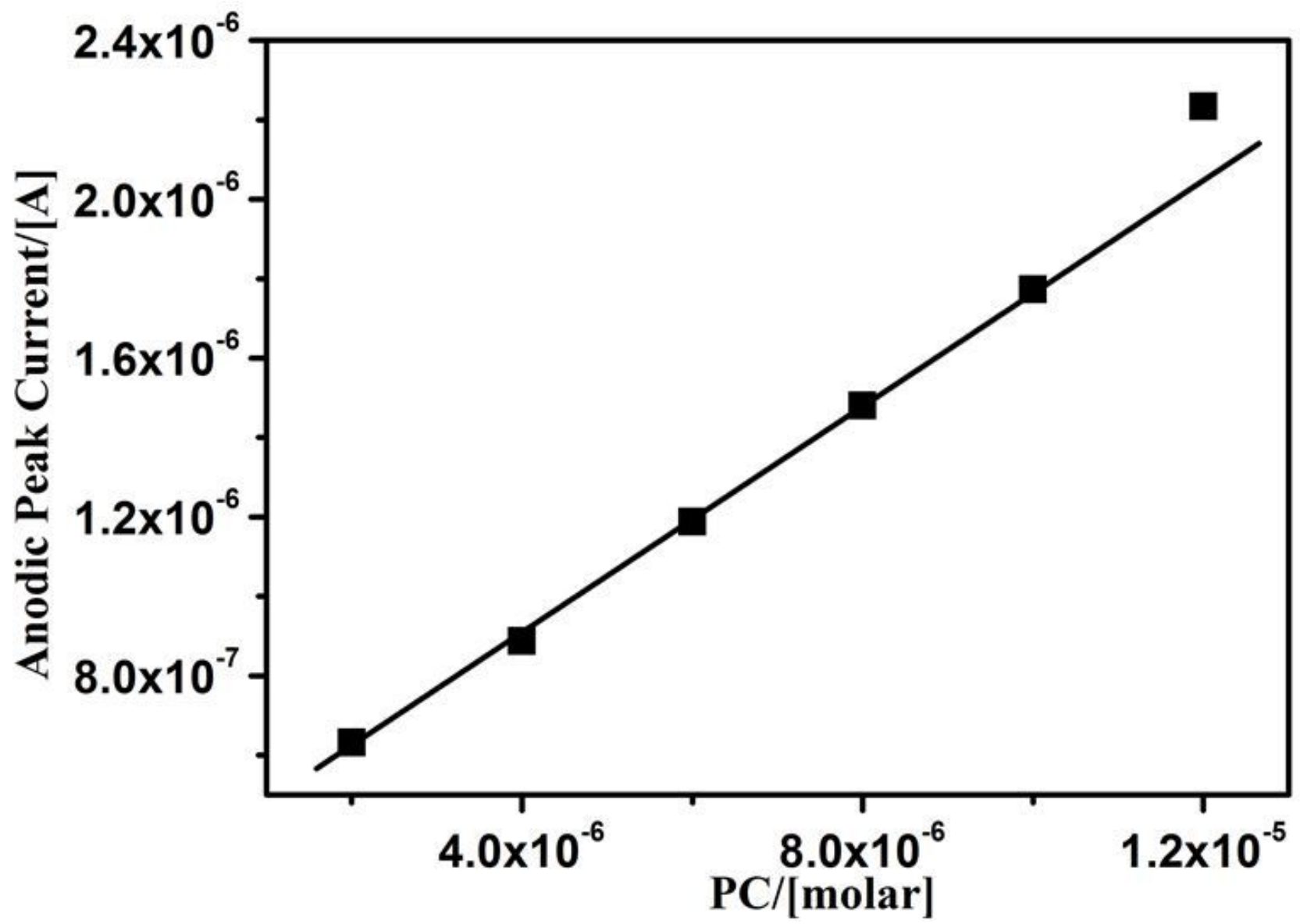

Figure 8

Graph of anodic Ipeak v/s PC concentration 


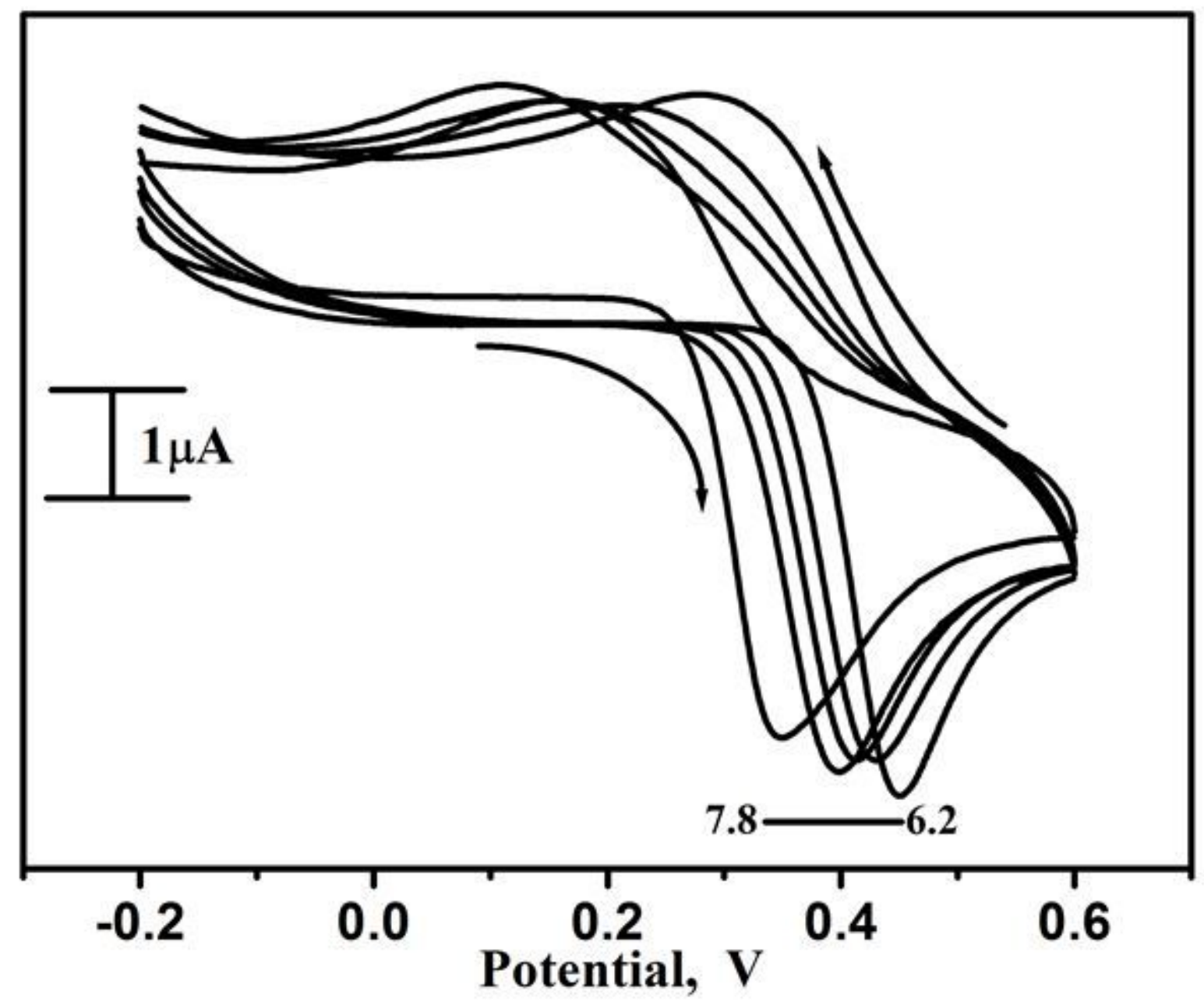

Figure 9

Cyclic voltammograms of oxidation of $10 \mu \mathrm{M}$ PC in $0.2 \mathrm{M}$ PBS of different $\mathrm{pH}$ at CuCrO4 NPs composite MCPE 


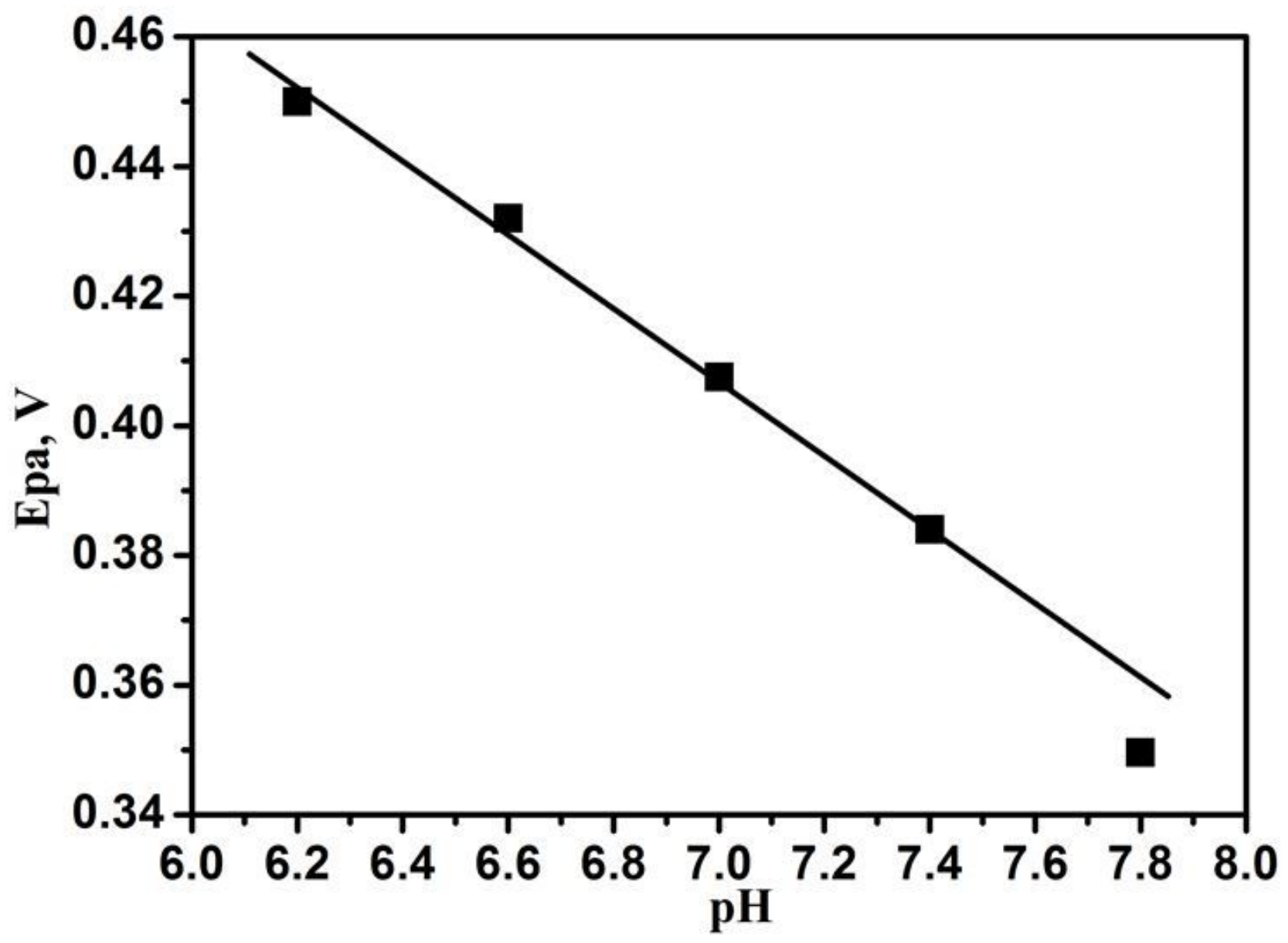

Figure 10

Graph of anodic peak potential versus $\mathrm{pH}$

Supplementary Files

This is a list of supplementary files associated with this preprint. Click to download.

- ga.jpg 